\title{
Developing the Law of the River: The Integration of Law and Policy into Hydrologic and Socio- Economic Modeling Efforts in the Willamette River Basin
}

\author{
Adell Louise Amos*
}

A legal and policy infrastructure-referred to as a "law of the river" - exists for every river basin in the U.S. and can be as important as natural processes in terms of managing the future of the resource. Because of the way that water law and policy have evolved in the U.S., this infrastructure involves a matrix of state and federal law that governs the choices that policymakers, end users, and agencies make. This "law of the river" provides the context in which decisions are made and not made. It also draws the boundaries within which decision makers believe they can operate. As a result, the law of the river and the policy choices that are faced can be interpreted as immovable or as constant in the larger decision-making dynamics of a river basin. Decision makers and stakeholders often claim definitiveness in terms of what the law can and cannot accomplish, and the legal questions are often presented as well settled and resolved. The law of the river, however, is as dynamic and active as the river itself, whether through the existing discretionary

\footnotetext{
* Associate Dean for Academic Affairs, Associate Professor \& Dean's Distinguished Faculty Fellow University of Oregon, School of Law. I would like to thank Margaret Townsend, Adam Walters, Malia Losordo and Kristina Schmunk Kraaz, all fellows with the University of Oregon's Oceans, Coasts, and Watersheds Project within the Environmental and Natural Resources Law Center for their superb research and writing in support of this project. They all have a passion for water law that is reflected in their work on this project. In addition, we are extremely grateful for the funding for these fellows, which was made available through the Environmental and Natural Resources Law (ENR) Center, and the incredible work, including project management and research, provided by Emily Johnson, the ENR Program Manager. The WW 2100 Project is supported by grants from the National Science Foundation and National Oceanic Atmospheric Agency. In particular, I want to acknowledge the generous support through NOAA funding, award \#NA10OAR4310218, for the Climate Impacts Research Consortium. This material is also based on work supported by the National Science Foundation under Award EAR-1038899. I also want to extend my sincere gratitude for my colleagues at the University of Oregon, Oregon State University, and Portland State University, particularly David Hulse, John Bolte, William Jaeger, Phil Mote, and Desiree Tullos. Their influence on this work can be seen throughout, and it is a joy to engage in this truly interdisciplinary effort.
} 
authority that the law has provided to those who are charged with implementing the law or ultimately through democracy's ability to change law based on the desires and needs of the public.

This paper explores the fundamental structure of state and federal law as it relates to the Willamette River Basin in Oregon, which is a familiar story for many basins in the U.S. Part I describes an interdisciplinary research project that seeks to integrate law and policy change into a set of future hydrologic scenarios on a hundred-year time scale for the Willamette Basin-the "Willamette Water 2100" project. ${ }^{1}$ Part II explains the value of integrating hydrologic modeling with law and policy on a basin scale. Part III begins to build a legal framework for both state and federal law and focuses on the particular pieces of those legal structures that are the most influential drivers for the management of water flow in the Willamette River. In addition, this part explores the inherent discretion and flexibility within existing law to help frame the conversation about what kinds of reasonable future scenarios can be explored for the basin. Part IV describes the process for building future flow scenarios for the Willamette River Basin using the inherent flexibilities in the existing legal infrastructure. Part V sets forth a set of preliminary conclusions and develops a set of research tasks that will drive the next stage of this work.

\section{A NEW KIND OF HYDROLOGIC-HUMAN SYSTEM MODEL-THE WILLAMETTE WATER 2100 PROJECT}

The Willamette River Basin (WRB), encompassing 30,000 square kilometers or $12 \%$ of the land area in Oregon, provides a rich and varied environment for studying inherent legal flexibilities to climate- and human-driven water scarcities. The physiography, orientation, and structure of the underlying geology create a grand landscape experiment for examining how different drivers of landscape change may impact water scarcity. In the Cascade Mountains to the east, glaciers and extensive regions of mid-elevation snowpack underlain by parallel units of low- and high-permeability volcanic bedrock may respond dramatically to even a few degrees of climate warming. In the Coast Range to the west, steep slopes underlain by low-permeability sedimentary rocks receive over 2500 millimeters of rainfall per year but

1. The official Willamette Water 2100 website is www.water.oregonstate.edu/WW2100/ project-overview. 
little snowfall. Tributaries of the Willamette River traverse the region's geological units and provide the opportunity to examine stream flow and vegetative response across a range of climatic, geologic, and ecological gradients and boundaries. The Willamette Valley is also an extremely fertile agricultural region, has a human population expected to double by 2050, and is home to the H.J. Andrews Experimental Forest, which is part of the National Science Foundation's (NSF) Long-Term Ecological Research (LTER) program.

The WRB is one of the best-characterized watersheds on earth. In 2005, the International Hydrological Programme of the United National Educational, Scientific and Cultural Organization (UNESCO) named the WRB as one of its HELP (Hydrology for the Environment, Life, and Policy) watersheds. The goal of the HELP program is to promote sustainable use of water by improving communication between hydrologists and water stakeholders. The basin contains about 250 stream-gauging stations. In the Cascades, eighteen SNOTEL (snow telemetry) stations operated by the U.S. Department of Agriculture's Natural Resources Conservation Service measure snowfall, precipitation, and air temperature at higher elevations and transmit the data to the National Water and Climate Center in Portland. Over the past fifty years, researchers have accumulated hydrological data that includes high temporal resolution flows, water chemistry, soil moisture, and plant transpiration in the H.J. Andrews Experimental Forest LTER site, an eco-hydrological observatory. Since 1991, a study unit of the U.S. Geological Survey's National Water Quality Assessment Program has operated in the WRB.

Oregon State University (OSU), the University of Oregon (UO), and Portland State University (PSU) are collaborating on a comprehensive, highly integrated examination of hydrological, ecological, and economic factors affecting water scarcity in the WRB. The team is developing a hydro-economic computer model using the Envision platform, a computing framework developed at OSU. ${ }^{2}$ The model will make it possible to explore how climate change, population growth, and economic growth will alter the availability and the use of water in the WRB. Envision provides a computing environment in which state-ofthe-art hydrological, ecological, and economic models interact

2. ENVISION: INTEGRATEd MOdEling PlatForm, A SPATIALly EXPlicit, Distributed, MULTIAGENT-BASED FRAMEWORK FOR POLICY ASSESSMENT AND ALTERNATIVE FUTURING, http://envision.bioe.orst.edu/About.aspx (last visited Mar. 8, 2014). 
synergistically. ${ }^{3}$ The team has the following objectives:

(1) Identify and quantify the linkages and feedbacks among human, hydrologic, and ecologic dimensions of the water system;

(2) Make projections about where and when human activities and climate change will impact future water scarcities, and evaluate how biophysical and human system uncertainties affect those projections;

(3) Create "alternative scenarios" where one or more policy levers or other interventions have been introduced into the model, and evaluate how these affect future water scarcities relative to the reference case scenario. By asking "what if?" questions in this way, policy analysis can provide the public and policymakers with a better understanding of options to prevent, mitigate, or adapt to water scarcities;

(4) Develop transferable tools and methods for projecting water scarcities and modeling policy alternatives.

The team is collaborating with public agents-government staff, resource managers, elected officials - and private stakeholders with strong interests in water as an integral element to the research process. County, state, and federal officials are involved to share their needs and perspectives and to help identify alternative scenarios.

The Willamette Water 2100 (WW 2100) project benefits from rich data resources and a legacy of integrative research. Beginning in 1995, the U.S. Environmental Protection Agency (EPA) sponsored the Pacific Northwest Ecosystem Research Consortium to conduct a seven-year, \$10 million study of the basin's future, which culminated in the publication of the Willamette River Basin Planning Atlas ${ }^{4}$ - the most comprehensive assessment of physical, biological, social, and aquatic factors ever assembled for a watershed of this size. Its authors and co-investigators considered three alternative scenarios for future development, all of which expect a doubling of the human population in the next forty years, and their likely impact on water availability, terrestrial habitats, and aquatic and terrestrial wildlife. In two of three scenarios for 2050, they found that the natural supply of water will not satisfy all out-of-stream demands and that some streams in the basin will go dry in the summers of years with low precipitation. ${ }^{5}$ In 2010, the National Oceanic and

3. $I d$.

4. Willamette River Basin Planning Atlas: Trajectories of Environmental and ECOlOGiCAL CHANGE (David Hulse et al. eds., 2d ed. 2002), available at http://www.fsl.orst.edu/pn werc/wrb/Atlas_web_compressed/PDFtoc.html.

5. Id. at 116 . 
Atmospheric Administration's (NOAA) Regional Integrated Sciences and Assessments program funded a consortium including coinvestigators to pursue stakeholder-driven climate research for landscape and watershed management in the Northwest.

The WRB, in particular, is an important location to conduct this kind of research. First, because of the Envision model and the considerable work of the WW 2100 project, there is an abundance of data and unprecedented anticipatory modeling capacity. Second, the Willamette Basin, while facing challenges, has not yet reached the level of water conflict and contentiousness seen in many basins in the western U.S. Because the Willamette Basin is not as conflict ridden as some other basins, it presents an opportunity to explore the power of discretionary authority at state and federal levels on a major river in the western U.S. without the hardened interests that, at a minimum, tend to discourage and, at worst, may eliminate such flexibility and cooperation at both institutional and operational levels. The results of this project will allow decision makers, stakeholders, and agency officials in the Willamette Basin to see the underlying legal and policy issues at play independent of a set of established interests and to pursue inherent flexibilities prior to a scarcity-driven crisis.

\section{INTEGRATING HYDROLOGIC AND ECONOMIC MODELING WITH LAW AND POLICY ON A BASIN SCALE}

Water law and policy in the U.S. is a fragmented jurisdictional framework that often requires an understanding of the complex interaction between state and federal law. ${ }^{6}$ The lack of thorough research regarding the interplay between federal and state law in the context of specific river basins often leads to considerable confusion and misinformation among decision makers about what the law can and cannot accomplish to resolve conflicts. Much of the wealth of legal scholarship, like the litigation of water issues, tends to focus on individual laws that impact freshwater resources or particular resource conflicts. This approach has illuminated and influenced many of the major crisis points and significant legal advancements in water law.

6. See, e.g., Robert Adler \& Michele Straube, Watersheds and the Integration of U.S. Water Law and Policy: Bridging the Great Divides, 25 WM. \& MARY EnVtL. L. \& POL'Y ReV. 1 (2000); Robert Adler, Addressing Barriers to Watershed Protection, 25 ENVTL. L. 973 (1995); Robin Kundis Craig, Climate Change, Regulatory Fragmentation, and Water Triage, 79 U. COLO. L. REv. 825 (2008). 
However, there is often not time nor resources to approach the entire legal landscape on a watershed scale to identify the main legal drivers and dynamics in the context of the hydrology and landscape of a particular river. ${ }^{7}$ Building the law of the river is also a complex task because the challenge of describing each aspect or law that impacts a particular watershed is as complex as trying to describe the whole ecosystem itself, though no less important. While this article begins to set forth the framework for the Willamette Basin, it is in no way comprehensive and is certainly a work-in-progress. It is in this context and with this as the goal that the work of the WW 2100 project has emphasized the need to approach the ecology of the legal infrastructure to unlock potential for adaptability and resilience in the system. However, there are exceptions that are often motivated by a particular water crisis or decision point, such as the Colorado, the Missouri, and the Mississippi River basins. ${ }^{8}$ Research is needed to build a law of the river for systems like the WRB in Oregon, particularly if those basins, like the Willamette, are not yet in crisis. As a result of the absence of a welldescribed and readily understood law of the river, issues between competing legal authorities are often not resolved; federal and state law issues are not reconciled until the parties are at the point of filing expensive and time-consuming litigation, and decision makers and stakeholders do not have access to the complete legal landscape that they are navigating. If we wait until the crisis point to develop an understanding of the law of the river, then solutions are retroactive, rather than anticipatory, and often more expensive and controversial to implement.

The arid western U.S. is particularly vulnerable to conflict in the face of water scarcity, given the way that human uses of water have been established and expanded over the landscape. This vulnerability is also

7. See generally Michael C. Blumm et al., Practiced at the Art of Deception: The Failure of Columbia Basin Salmon Recovery Under the Endangered Species Act, 36 ENVTL. L. 709 (2006) (discussing the difficulties encountered in protecting Columbia River Salmon under the ESA); Janet C. Neuman et al., Sometimes a Great Notion: Oregon's Instream Flow Experiments, 36 ENVTL. L. 1125 (2006) (discussing the successes and failures of Oregon's instream flow program); Michael Healy, Still Dirty After Twenty-Five Years: Water Quality Standard Enforcement and the Availability of Citizen Suits, 24 ECOLOGY L. Q. 393 (1997) (discussing shortcomings of the Clean Water Act).

8. E.g., Christine Klein \& Sandra Zellmer, Mississippi River Stories: Lessons from a Century of Unnatural Disasters, 60 SMU L. REv. 1471 (2007); Sandra Zellmer, A New Corps of Discovery of Missouri River Management, 83 NeB. L. Rev. 305 (2004); Lawrence J. MacDonnell et al., The Law of the Colorado River: Coping with Severe Sustained Drought, 31 J. AM. WATER RES. Ass'N 825 (1995). 
due, in part, to the governance of water allocation by the doctrine of prior appropriation (hereinafter "prior appropriation") adopted by each of the seventeen western states to control the allocation of water rights. ${ }^{9}$ The relationship between human uses of water and the law that is established makes sense because the law is a reflection of the way that people allocate these resources. As a result, prior appropriation is often critiqued as an antiquated and inflexible system for resource management and allocation but may also have some valuable unexplored or unenforced tools. ${ }^{10}$ In addition to state law systems, for the vast number of river basins in the western U.S., including the Willamette River, federal law-including the Endangered Species Act, the Clean Water Act, and authorization for Army Corps of Engineers projectsprovides a significant, if not controlling, overlay to the state appropriative system. The interaction between these state and federal water laws provides the public policy framework in which decision makers operate as they address the challenges that society faces with regard to changes in the freshwater system.

Meanwhile, we are living through a period of unprecedented change in coupled social-ecological—or human-natural—systems, adding substantial stress to the management of freshwater resources. ${ }^{11}$ Massive, irreversible losses of ecosystem services and growing pressures from the combined effects of economic growth, population growth, and climate change are evident, with increasing frequency, in more and more corners of the world. ${ }^{12}$ These dramatic ecosystem changes are at the center of substantial conflict over water resource allocation in many locations. For example, the California Delta, at the confluence of the Sacramento and San Joaquin rivers, represents an area immersed in conflict due to loss of

9. Adell Amos, Freshwater Conservation in the Context of Energy and Climate Policy: Assessing Progress and Identifying Challenges in Oregon and the Western United States, $12 \mathrm{U}$. DENV. WATER L. REV. 1, 133-35 (2008).

10. See Reed D. Benson, Alive but Irrelevant: The Prior Appropriation Doctrine in Today's Western Water Law, 83 U. Colo. L. ReV. 675, 689-90 (2012); Janet C. Neuman, Beneficial Use, Waste, and Forfeiture: The Inefficient Search for Efficiency in Western Water Use, 28 ENVTL. L. 919 (1998).

11. Charles J. Vörösmarty et al., Global Threats to Human Water Security and River Biodiversity, 467 NATURE 555, 555-61 (2010); Daren M. Carlisle et al., Alteration of Streamflow Magnitudes and Potential Ecological Consequences: A Multiregional Assessment, 9 FrONTIERS ECOLOGY \& ENV'T 264-70 (2011), available at http://water.usgs.gov/nawqa/pubs/Carlisleetal_ FLowAlterationUS.pdf.

12. Charles J. Vörösmarty et al., Global Water Resources: Vulnerability from Climate Change and Population Growth, 289 SCI. 284, 284-88 (2010); Casey Brown et al., Decision Scaling: Linking Bottom-up Vulnerability Analysis with Climate Projections in the Water Sector, 48 WATER RES. RESEARCH, Sept. 21, 2012, at 1-12. 
fish species and restrictive actions imposed by both federal and state law. ${ }^{13}$ This climate has resulted in uncertainties about future water and regulatory environments and costly lawsuits. The conflict centers around the volume and timing of water needed for protection of aquatic organisms and water diverted for agriculture, municipal, and industrial uses. This conflict has elicited calls for changes in western water law. ${ }^{14}$

Due to increased awareness of these complex interactions among social and ecological systems, both the public and private sectors have increasingly turned to scientific, quantitative methods to inform land and water policy and decision making in the presence of uncertainty. By encompassing a broad range of future possibilities and uncertainties, such as local manifestations of global climate change, the WW 2100 model is creating the ability to better anticipate and respond to problems related to water scarcity. By virtue of the ability of the model to ask "what if" questions by simulating broad sets of alternative scenarios, this kind of research has the potential to evaluate future trajectories of change and to serve as a constructive means for forging consensus among diverse groups of citizens and policymakers before the conflict is upon them. ${ }^{15}$

13. See generally Christine A. Klein, Water Bankruptcy, 97 MiNN. L. Rev. 560, 612 (2012); David Fullerton, Summary and Analysis: Principles of Agreement on Bay Delta Standards Between the State of California and the Federal Government, 14 HASTINGS W.-Nw. J. ENVTL. L. \& POL'Y 179 (2008); Alf W. Brandt, An Environmental Water Account: The California Experience, 5 U. DenV. Water L. Rev. 426 (2002); David J. Hayes, Federal-State Decisionmaking on Water: Applying Lemons Learned, 32 ENVTL. L. REPORTER 11253 (2002).

14. National ACADEMy of Sciences, Sustainable Water and EnVIRONMENTAL MANAGEMENT IN THE CALIFORNIA BAY-DELTA 204-05 (2012) (outlining changes that California could make to better respond to uncertainty).

15. One approach in such assessments has been characterized as a predict-then-act paradigm, which pairs models of rational decision making with methods for treating uncertainty, derived largely from the sciences and engineering. Robert Lempert et al., Characterizing Climate-Change Uncertainties for Decision-Makers: An Editorial Essay, Climate Change, 2004, at 1. The preferred course of action in predict-then-act assessments is the one that performs "best" given some typically small set of assumptions about the likelihood of various futures and the critical processes that will be sustained if these assumptions prove true. Researchers have argued that these approaches face challenges, especially when applied over the spatial and temporal extents at which important ecological processes operate, and in relation to the ecosystem goods and services on which people rely. C.S. Holling, Understanding the Complexity of Economic, Ecological, and Social Systems, Ecosystems, 2001, at 390; KM Chan et al., Conservation Planning for Ecosystem Services, PLOS BIOLOGY, Oct. 4, 2006, available at http://www.ncbi.nlm.nih.gov/pubmed/17076586. In contrast, the explore-then-test approach seeks actions that are shown to perform well across a large number of plausible future alternatives. David Hulse et al., Anticipating Floodplain Trajectories: A Comparison of Two Alternative Futures Approaches, J. LANDSCAPE ECOLOGY, Oct. 2009, at 1067-90; Brown, supra note 12, at 1-12. By encompassing a broad range of future possibilities and uncertainties, such as local manifestations of global climate change, these approaches offer greater potential to be responsive to opportunities and 
In western Oregon's WRB, the NSF-funded WW 2100 project, slated to end in 2015, is underway. This five-year project is investigating how climate change, population growth, and economic growth will change the availability and the use of water in the basin on a decadal to centennial timescale. The project is implementing a transferable method designed to predict where climate and economic change will create water scarcities and where those scarcities will exert the strongest impacts on human society. The WW 2100 project utilizes a software simulation platform called Envision. Envision is a sophisticated simulation environment that has been widely used in projects throughout North and South America in situations where understanding and anticipating coupled social-ecological — or human or natural-system trajectories is central to wise resource use and management. ${ }^{16}$ WW 2100 uses the Envision computer platform to integrate hydrology, economics, law, and policy to describe system interactions and feedbacks, and to predict future changes in the supply, demand, and allocation of water.

With that foundation on the work of WW 2100 in mind, the purpose of this article is to highlight the legal infrastructure that has contributed to this project with a particular focus on the legal and policy aspects that impact flow in the mainstem of the Willamette River and to set forth some future research questions that we hope to address. As a result of the fragmented nature of federal and state legal and policy authority over water, there is often a lack of focus and energy on the flexibility and adaptability embodied within existing law. The focus is often on how broken and antiquated our water allocation systems are, as discussed above, on how difficult it is to navigate the state and federal dynamics, and on ways to completely reinvent the way in which we allocate water. ${ }^{17}$ This article explores an alternate approach by attempting to

adaptive to problems. By virtue of their exploration of broad sets of contingencies, they also have the potential to serve as constructive means for forging consensus among diverse groups of citizens and policymakers. Lempert, supra note 15, at 1; Hulse, supra note 15, at 1067-90. Given the complexities of managing critical resources in the context of unprecedented future change, researchers in social and environmental sciences are increasingly employing agent-based simulation models to employ an explore-then-test paradigm as a means of anticipating problems before they arise. Hulse, supra note 15, at 1067-90.

16. Hulse, supra note 15, at 1067-90; Michael R. Guzy et al., Policy Research Using AgentBased Modeling to Assess Future Impacts of Urban Expansion into Farmlands and Forests, $13 \mathrm{~J}$. ECOLOGY \& SoC'Y, no. 1, 2008, at 37; John P. Bolte et al., Modeling Biocomplexity-Actors, Landscapes and Alternative Futures, 22 J. EnvTL. ModELING \& SOFTwARE 570, 570-79 (2006).

17. See, e.g., Neuman, supra note 10, at 920 (recounting the growth of beneficial use, the doctrine's inability to address waste and efficiency concerns, and potential reforms); Michael C. Blumm \& Thea Schwartz, Mono Lake and the Evolving Public Trust in Western Water, 37 ARIZ. L. REV. 701 (1995) (reviewing the emergence and spread of judicial decisions that apply the public 
identify the inherent flexibility and adaptability embedded within existing law - and people's response to those changes - and focusing on ways that the existing legal framework may present more opportunity to address change in the future. The underlying idea animating this work grows from the notion that there is inherent discretionary authority in the existing structure of water law, that this discretionary authority has not been fully explored or implemented, and that it may provide the adaptive capacity to address changed future circumstances. ${ }^{18}$

The ultimate goal for the legal work associated with this larger effort seeks to: (1) evaluate the relationship between state and federal water law and policy and identify where there is sufficient flexibility to allow for changes in the ways the resource is managed in light of anticipated climate and population changes; (2) use anticipatory modeling to explore the effects of different discretionary choices on future water deficits and scarcity in the WRB; and (3) analyze and evaluate proposed changes to law and policy that would provide increased flexibility in the Basin's water management and share this information with stakeholders and decision makers in the basin.

\section{BEGINNING TO BUILD THE LAW OF THE WILlAMETTE RIVER: UNDERSTANDING THE COMPONENTS OF FEDERAL AND STATE WATER LAW AS THEY RELATE TO INSTREAM FLOW ON THE MAINSTEM WILLAMETTE}

Understanding the law today of any river in the U.S. requires one to grapple with the relationship between state and federal law. Water law is a creature of state law. At its most fundamental, water is a public resource and all water within the State of Oregon is managed and owned by the state. ${ }^{19}$ Moreover, water is subject to the principles of the public

trust doctrine to counteract environmental degradation under prior appropriation regimes); Robert W. Alder, Addressing Barriers to Watershed Protection, 25 ENVTL. L. 973, 1015-17, 1098, 1100 (1995) (noting the cumulative challenges of prior appropriation's predominance in western states, de facto adoption of beneficial use under federal reclamation laws, and federal water resource agencies' tendency to prioritize water use over preservation); Eric T. Freyfogle, Water Justice, 1986 U. ILL. L. REV. 481, 492-99 (1986) (criticizing the efficiency and equity of first-in-time allocation systems).

18. See J.B. Ruhl, General Design Principles for Resilience and Adaptive Capacity in Legal Systems - with Applications to Climate Change Adaptation, 89 N.C. L. REV. 1373, 1388-93 (2011) (defining adaptive capacity and explaining how legal systems accomplish it); Barbara Cosens, Transboundary River Governance in the Face of Uncertainty: Resilience Theory and the Columbia River Treaty, 30 J. LAND RES. \& ENVTL. L. 229 (2010) (noting aspects of adaptive management in the Columbia River system governance and options for developing administrative law resiliency).

19. See OR. REV. STAT. $§ 537.110$ ("All water within the state from all sources of water supply belongs to the public," including groundwater); see also id. $\$ 537.525$. With limited exceptions, 
trust doctrine, although the contour and scope of the doctrine varies by state. $^{20}$ To carry out its water management duties and its obligations to care for this public resource, each western state has adopted the system of prior appropriation to allocate rights to citizens to use surface waters, including provisions to protect non-consumptive use. ${ }^{21}$ The prior appropriation system of water rights is well known to those in the West based on its "first in time, first in right" priority system and the principle of "use it or lose it."22 This allocation model, as explained in more detail below, forms the backbone of state law that governs the WRB, as well as all river basins in Oregon and throughout the western U.S. In addition, the vast majority of states, Oregon included, have adopted a regulatory framework, consistent with the Clean Water Act, to address water quality. ${ }^{23}$

State law does not capture the full legal landscape of the Willamette River or of most rivers in the western U.S. today. While state law is the appropriate starting point for understanding the law of the river, the dynamics involving federal law can quickly overtake the state law structure. In particular, for the WRB, the creation of the Willamette River Project by Congress and role of the Army Corps of Engineers (USACE) loom large in terms of the on-the-ground realities for management of the Willamette River system. In addition to the authority and discretion exercised by USACE, the role of the Endangered Species Act and the Clean Water Act, as implemented by the state, sets much of the framework for non-consumptive use in the basin. Each of these statutes operate as a distinct set of statutory and regulatory requirements,

water users must acquire a permit from the Oregon Water Resources Department before appropriating water. See id. § 537.130; William F. Cloran, The Ownership of Water in Oregon: Public Property vs. Private Commodity, 47 Willamette L. Rev. 627, 646-47 (2011) (discussing state ownership of water). The Oregon Water Resources Department has established rules and procedures for allocating water resources through the permitting process. See generally OR. ADMIN. R. 690 (2013).

20. See Robin K. Craig, A Comparative Guide to the Western States' Public Trust Doctrine: Public Values, Private Rights, and the Evolution Toward an Ecological Public Trust, 37 ECOLOGY L.Q. 53, 161-70 (2010) (summarizing Oregon's public trust doctrine, including relevant constitutional provisions, statutes and cases); Michael C. Blumm \& Erika Doot, Oregon's Public Trust Doctrine: Public Rights in Waters, Wildlife and Beaches, 42 ENVTL. L. 375 (2012) (discussing the history of the public trust doctrine in Oregon); Joseph L. Sax, The Public Trust Doctrine in Natural Resource Law: Effective Judicial Intervention, 68 MicH. L. REV. 471 (1970).

21. Adam Schempp, Western Water in the 21st Century: Policies and Programs that Stretch Supplies in a Prior Appropriation World, 40 ENVTL. L. REP. NEWS \& ANALYSIS 10394, 10394-395 (2010).

22. Id. at 10395.

23. See, e.g., OR. Rev. Stat. § 468B.035 (2001) (implementing the Clean Water Act in Oregon). 
but also interact with the other requirements at the state and federal level to create the complex web called the law of the river. The next portion of this article begins with a summary of three significant federal components of the law of the river for the Willamette Basin, including the creation of the Willamette Project to be operated by the USACE, the implementation of the Endangered Species Act in the Willamette Basin, and the regulatory framework established by the Clean Water Act. The article then turns to Oregon's state water law and looks, in particular, at the state law provisions that drive flow on the mainstem of the Willamette River, including the basics of water rights allocation, the definition of beneficial use, the water transfer process, water measurement, and the mechanism under state law to protect nonconsumptive use.

\section{A. Congressional Authorization of the Willamette Project}

After a series of devastating floods in the first part of the twentieth century, Congress legislatively recognized that, because floods upset the country's orderly processes, cause loss of life and property, and impair channels of commerce between the States, flood control is a proper activity of the Federal Government with cooperation of the states. ${ }^{24}$ Congress assigned the Secretary of War and the Chief of Engineers with the job of investigating and improving the nation's waterways in regards to flood control and "allied purposes.", 25

However, beyond recognizing flood control as a federal concern and appointing the officials from the War Department to investigate the situation, Congress did not provide much instruction as to how to proceed. Instead, it instructed the Secretary of War and Chief of Engineers to carry out their tasks under this guideline: improve waterways for flood-control purposes in instances when the benefits will outweigh the costs and people's safety and security are at risk. ${ }^{26}$ Otherwise, the War Department was responsible for figuring out how

24. Flood Control Act of $1936 \S 1$, Pub. L. No. 74-738, 49 Stat. 1572 (1936) (codified as amended at 33 U.S.C. § 701a (2006)); see also A. Dan Tarlock, A First Look at a Modern Legal Regime for a "Post-Modern" United States Army Corps of Engineers, 52 U. KAN. L. REV. 1285, 1301, 1303-04 (2004) (noting the addition of flood control responsibilities to the USACE's mission); Christine A. Klein, On Dams and Democracy, 78 OR. L. REV. 641, 661 (1999) (discussing the authority of the USACE after the Flood Control Act of 1936).

25. Flood Control Act of $1936 \S 2$; see also Alder, supra note 17, at 1025 n.301.

26. Flood Control Act of $1936 \S 1$; see also Klein, supra note 24, at 679-82 (noting the costbenefit mandate and criticizing the USACE's observance of that requirement). 
best to address and manage flood risks in the nation's many susceptible areas. Any plans were then to be submitted to Congress for approval. ${ }^{27}$

One of the waterways investigated by the USACE was the WRB. In the 1930s, the USACE produced a report on the basin's susceptibility to flooding. This report included suggested plans for structurally safeguarding the basin from future flooding. Upon review, Congress authorized the USACE's plans to safeguard the WRB. ${ }^{28}$ First, in 1936, Congress authorized bank protection works at several localities in the Willamette Basin. ${ }^{29}$ Then, in 1938, Congress approved the USACE's general comprehensive plan for flood control and navigation in the Willamette Basin, which consisted primarily of a plan to build a system of reservoirs along the tributaries of the Willamette River. ${ }^{30}$ Over the next several decades, the USACE built a series of thirteen dams on tributaries of the Willamette River as part of the Willamette Project.

In 1944, Congress assigned the Secretary of War with the duty to prescribe regulations for "the use of storage allocated for flood control or navigation at all reservoirs constructed wholly or in part with Federal funds provided on the basis of such purposes," and stated that "the operation of any such project shall be in accordance with such regulations." 31 In other words, Congress gave the Secretary of War not only the power, but also the duty to create the rules and regulations under

27. Compare Flood Control Act of $1954 \S 202$, Pub. L. No. 83-780, 68 Stat. 1256 (as codified at 33 U.S.C. $\$ 701$ b-8 (2006)) ("No project or any modification not authorized, of a project for flood control ... shall be authorized by the Congress unless a report for such project or modification has been previously submitted by the Chief of Engineers ...."), with Flood Control Act of $1948 \S 205$, Pub L. No. 80-858, 62 Stat. 1182 (codified as amended at 33 U.S.C. § 701s (2006)) ("The Secretary of the Army is authorized to allot from any appropriations ... for the implementation of small structural and nonstructural projects for flood control and related purposes not specifically authorized by Congress"); see also Alder, supra note 17, at 1027 (noting that "Congress retain[s] principal authority to decide on a case-by-case basis which projects should be funded.").

28. See Community Planning Toolbox: WRDAs and Related Laws, U.S. ARMY CORPS OF ENG'RS (Apr. 2014), http://planning.usace.army.mil/toolbox/guidance.cfm?Option=WRDALaw\& Side=No\&Type=River\%20and\%20Harbor\%20Acts (last visited Feb. 13, 2014).

29. Flood Control Act of $1936 \S 5$ ("[T]he following works of improvement, for the benefit of navigation and the control of destructive flood waters and other purposes are hereby adopted and authorized to be prosecuted ... under the discretion of the Secretary of War and supervision of the Chief of Engineers in accordance with the plans in the respective reports and records hereinafter designated ... WILLAMETTE RIVER. Construction of bank-protection works, with channel clearing on the Willamette River ... in Oregon, for the reduction of flood heights and to prevent loss of land by erosion; special report in Office of the Chief of Engineers; estimated construction cost, $\$ 2,430,000$.”).

30. Flood Control Act of $1938 \S 2$, Pub. L. No. 75-761, 52 Stat. 1215 (codified as amended at 33 U.S.C. $\$ 701-1$ (b) (2006)).

31. Flood Control Act of $1944 \S 7$, Pub. L. No. 78-534, 58 Stat. 887 (codified as amended at 33 U.S.C. § 709 (2006)). 
which federal flood control and navigation projects must be operated. Again, this represents a broad grant of authority.

The USACE itself states that it has "a high degree of operational flexibility . . . in determining how to meet the authorized purposes." ${ }^{32}$ While Congress originally authorized construction of the Willamette Project to protect against flooding and support navigation, today the project is also authorized for irrigation, water quality, fish and wildlife enhancement, and recreation purposes. ${ }^{33}$

The USACE's Standard Operating Plan for the Willamette Project states that "[i]n general, NWP has the responsibility for Willamette Basin system wide flood control, developing daily schedules, and coordinating requests for special operations with other agencies. The operators are responsible for local flood control, meeting project operating criteria, schedule implementation, project emergencies and forwarding requests to NWP for special operations." ${ }^{\text {34 }}$ The USACE has articulated its authority for operating the Willamette Project to include responsibility for system-wide flood control, including developing daily schedules and coordinating requests for special operations with other agencies addressing local flood control, meeting project operating criteria, implementing schedules, and addressing project emergencies. ${ }^{35}$

One rule falling under this broad authority is the "rule curve." The rule curve indicates the maximum elevation to which the USACE can fill a reservoir during various times of the year, with the exception of realtime flood operations. ${ }^{36}$ Congress neither created the rule curve nor instructed the USACE to operate by it - the rule curve was created by the

32. Coast Fork Willamette River, Oregon Surplus Water Letter Report, US ARMY CORPS OF ENG'RS: PORTLAND DIST. (Dec. 18, 2013), http://www.oregon.gov/owrd/docs/draft_Consolidated_ Surplus_Water_Supply_Letter_Report_18Dec2013.pdf.

33. Willamette Valley-Operating the Reservoirs: Introducing the Rule Curve, US ARMY CORPS OF ENG'RS: PORTLAND DIST., http://www.nwp.usace.army.mil/Portals/24/docs/pubs/WV water_mgmt_FS_2011a.pdf (last viewed Feb. 13, 2014).

34. U.S. ARMY CORPS OF ENG'RS: Portland Dist., WillametTe Basin Guide: STANDARD OPERATING PROCEDURE (SOP) FOR RESERVOIR CONTROL CENTER (on file with author).

35. Id.; see also Flood Control Act of 1938 § 4, Pub. L. No. 75-761, 52 Stat. 1215, 1222; Flood Control Act of $1950 \S 204$, Pub. L. No. 81-516, 64 Stat. 163, 178-79; Flood Control Act of $1960 \S$ 203, Pub. L. No. 86-645, 74 Stat. 480, 499; U.S. ARMY Corps OF ENG'RS: PORTLAND DisT.,

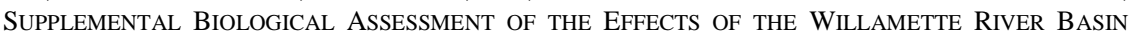
Flood Control Project on Species Listed Under the Endangered Species ACt 2-4 n.1 (2007), available at http://www.nwp.usace.army.mil/Portals/24/docs/environment/biop/Final_Will_ Suppl_BA.pdf (stating that the Willamette Project's authorization derives principally from the Flood Control Acts of 1938, 1950, and 1960).

36. Willamette Valley-Operating the Reservoirs, supra note 33. 
USACE and can be amended by the USACE. ${ }^{37}$

However, it should be noted that 33 U.S.C. $\S 701 b-8$ states that "[n]o project or any modification not authorized, of a project for flood control or rivers and harbors, shall be authorized by the Congress unless a report for such project or modification has been previously submitted by the Chief of Engineers, United States Army, in conformity with existing law." 38 While it is uncertain whether amending a rule curve requires a report to Congress for approval, a history of congressional deference to the USACE in matters concerning flood control would suggest that obtaining congressional approval would not be impossible. ${ }^{39}$ Thus, assertions that the USACE is legally bound to the current rule curve seem counterintuitive to the history and context of the USACE relationship with Congress. The technical and engineering considerations that are an inherent part of the rule curve may require very careful and deliberate decision making before any change could be implemented.

37. See John R. Seeronen, Judicial Challenges to Missouri River Mainstem Regulation, 16 Mo. ENVTL. L. \& POL'Y REV. 60, 61-64, 67, 89 (2009) (reviewing the congressional authorization for the USACE to create and implement flood control and reservoir regulations in the Missouri Mainstem, resulting in an operation manual that addressed flood control, irrigation, water supply, navigation, hydropower, recreation, and environmental uses; noting Government Accountability Office criticism of the USACE stance that new congressional authorization was necessary for the USACE to change operational priorities; and stating that " " $[\mathrm{t}]$ here is no language in either case law or legislative history that dictates that the Corps must always maintain a particular water level or specific water season in its river operations." (quoting In re Operation of the Mo. River Sys. Litig., 363 F. Supp. 2d 1145, 1153 (D. Minn. 2004), aff'd in part, rev'd in part on other grounds, 421 F.3d 618 (8th Cir. 2005))); Robin Kundis Craig, Adapting Water Law to Public Necessity: Reframing Climate Change Adaptation as Emergency Response and Preparedness, 11 VT. J. ENVTL. L. 709, 727 (2010) ("Reservoir operations are governed by 'rule curves' .... Developed by the U.S. Army Corps of Engineers based on historical flood data, many of these rule curves have never been modified, and modifications might require Environmental Impact Statements."); but see Robert Haskell Abrams, Water, Climate Change, and the Law: Integrated Eastern States Water Management Founded on a New Cooperative Federalism, 42 ENVTL. L. REP. NEwS \& ANALYSIS 10433, 10445-446 (2010) (noting that "major ... operational changes" to USACE reservoir storage require congressional authorization under the Water Supply Act of 1958 when water is allocated to municipal uses (quoting 43 U.S.C. $\S 390 \mathrm{~b}(\mathrm{~d})$ )).

38. 33 U.S.C. $\$ 701 b-8$ (1954).

39. See Oliver A. Houck, Breaking the Golden Rule: Judicial Review of Federal Water Project Planning, 65 RUTGERS L. REV. 1, 1 (2012) ("The law behind Corps projects is scanty and the discretion virtually unbridled."); Jeffrey T. Mason, Interstate Water Compact Version 3.0: Missouri River Basin Compact Drafters Should Consider an Inter-Sovereign Approach to Accommodate Federal and Tribal Interests in Water Resources, 88 N.D. L. REV. 97, 101 \& n.9 (2012) (“"The Flood Control Act clearly gives a good deal of discretion to the Corps in the management of the River."' (quoting South Dakota v. Ubbelohde, 330 F.3d. 1014, 1027 (8th Cir. 2003))); Klein, supra note 24, at 725-26 (noting Congress' "“dazzlingly uninquisitive"' deference to USACE flood control decision up until the 1980s) (quoting Wendy Nelson Espeland, Authority By the Numbers: Porter on Quantification, Discretion, and the Legitimation of Expertise, 22 L. \& SOC. INQUIRY 1107 (1997)). 
In sum, Congress has granted the USACE broad authority in how it investigates, constructs, and operates flood control projects, including the Willamette Project, which is like so many of the projects the USACE operates throughout the U.S. Fully utilizing this operational flexibility is an important tool for the future management of the mainstem flow of the Willamette River. Though not without controversy and considerable technical engineering limitations, the USACE, as a legal matter, retains significant operational discretion. Questions remain, however, as to when and where the USACE will choose to deploy the full measure of operational flexibility given the competing purposes for and demands on the thirteen federally-managed reservoirs in the Willamette Basin.

\section{B. Endangered Species Act}

The Endangered Species Act (ESA) was enacted in 1973, offering the nation a federal program "whereby the ecosystems upon which endangered species and threatened species depend may be conserved." Congress would accomplish these goals through "a comprehensive suit of affirmative mandates, strict prohibitions, strong recommendations, and limited exception." 41 Such robust language reflects what the U.S. Supreme Court pinpointed as the ESA's clear purpose: "to halt and reverse the trend toward species extinction, whatever the cost." ${ }^{42}$ It is difficult to state strongly enough the impact that the ESA has had on the management of water resources in the U.S. ${ }^{43}$ In many river basins, the operation of the ESA has been one of the more significant legal drivers for change to the existing water management regime. ${ }^{44}$

The ESA has four major parts. Section 4 addresses which species and habitats are protected by the ESA. ${ }^{45}$ Section 9 prohibits activities that would affect listed species and habitats. ${ }^{46}$ Section 10 creates a permit system that allows for exceptions to the "take" prohibitions in

\footnotetext{
40. 16 U.S.C. $§ 1531$ (b) (2006).

41. Tony A. Sullins, The Endangered SpeCies Act 2 (2d ed. 2001).

42. Tenn. Valley Auth. v. Hill, 437 U.S. 153, 180 (1978).

43. See, e.g., Klein, supra note 24 , at 698 n.381.

44. David H. Getches, The Metamorphosis of Western Water Policy: Have Federal Laws and Local Decisions Eclipsed the States' Role?, 20 STAN. EnVTL. L.J. 3, 53 (2001); Reed D. Benson, So Much Conflict, Yet So Much in Common: Considering the Similarities between Western Water Law and the Endangered Species Act, 44 NAT. RESOURCES J. 29 (2004).

45. See 16 U.S.C. $\S 1533$.

46. See id. $\$ 1538$.
} 
Section 9. ${ }^{47}$ Finally, Section 7 details how the federal government must conduct itself to advance the ESA's conservation goals. ${ }^{48}$ The ESA also includes provisions that encourage federal-state cooperation and allow private citizens to aid in carrying out the law's purpose. ${ }^{49}$ All of these provisions have impacted the WRB, particularly the flow regime for the mainstem of the Willamette, as discussed in more detail below.

\section{Section 4-Listing a Species as Endangered or Threatened}

Section 4 explains how species become listed as endangered or threatened under the ESA. ${ }^{50}$ The listing decision is delegated to the U.S. Fish and Wildlife Service and the National Marine Fisheries Service ("the Service(s)"). ${ }^{51}$ These decisions are made using the best scientific and commercial data available. ${ }^{52}$ Commercial data is limited to details about the trade in a candidate species; otherwise, listings are not based on economic concerns. ${ }^{53}$ When listing a species as endangered or threatened, the Services generally must produce recovery plans for the species and report to Congress about that species' progress toward recovery. ${ }^{54}$

Besides listing species as endangered or threatened, the ESA seeks for listed species' habitat to be protected. ${ }^{55}$ The Services also designate critical habitat according to the best available scientific and commercial data, but may also consider economic factors. ${ }^{56}$ Critical habitat is not necessarily designated when a species is listed, but may be designated up to one year later. ${ }^{57}$ When considering an area as critical habitat, the Services must give special thought to the species' essential needs, such as spawning sites, feeding sites, and water quality and quantity. ${ }^{58}$ While Section 4 requires the Services to identify species for listing and territory

\footnotetext{
47. See id. $\S 1539$.

48. See id. $\$ 1536$.

49. See id. $\S \S 1535,1540$.

50. Id. $\S 1533(\mathrm{a})$.

51. See, e.g., id. § 1533(a)(1) \& (2); 50 C.F.R. § 402.01.

52. Id. $\S 1533(\mathrm{~b})(1)(\mathrm{A})$.

53. See H.R. REP. No. $97-567$ (1982), reprinted in 1982 U.S.C.C.A.N. 2807, 2820; H.R. CONF. REP. No. 97-835 (1982), reprinted in 1982 U.S.C.C.A.N. 2860, 2861.

54. 16 U.S.C. $\S 1533(\mathrm{f})(1) \&(3)$.

55. Id. $\S \S 1532(5)(\mathrm{A}), 1533(\mathrm{a})(3)(\mathrm{A})$.

56. Id. § 1533(b)(2); H.R. REP. No. 97-567, reprinted in 1982 U.S.C.C.A.N. 2807, 2812.

57. 16 U.S.C. $\S 1533$ (b)(6)(C)(ii).

58. 50 C.F.R. $\$ 424.12(\mathrm{~b})$.
} 
for critical habitat, the ESA also authorizes private citizens to participate - any interested person may petition the Secretaries to list a species or designate critical habitat. ${ }^{59}$

In the WRB, there are four listed fish species that influence many of the regulatory decisions regarding flow on the Willamette River. Beginning in 1993, the U.S. Fish and Wildlife Service (USFWS) listed the Oregon Chub as endangered under the ESA with the only remaining population residing in an 18.6 mile stretch of the Middle Fork Willamette River Drainage. ${ }^{60}$ There has been no critical habitat designated for the Oregon Chub. In 1998, the USFWS listed the Columbia River population of bull trout as threatened under the ESA, and then, in 2005, the USFWS designated critical habitat for the WRB distinct population segment of this species. ${ }^{61}$ In addition, the USFWS drafted a Bull Trout Recovery Plan that includes significant measures in the McKenzie River, a tributary to the Willamette River. ${ }^{62}$ In 1999, the National Marine Fisheries Service (NMFS) listed the upper Willamette River chinook salmon and the upper Willamette River steelhead as threatened under the ESA. $^{63}$ In 2000 and again in 2005, the NMFS designated critical habitat for the chinook salmon, and the Biological Status Review in 2005 noted that the Oregon Department of Fish and Wildlife (ODFW) identified only one remaining naturally producing population within the evolutionarily-significant unit of spring-run chinook in the McKenzie River, a tributary of the Willamette. ${ }^{64}$ For the upper Willamette steelhead, the NMFS designated critical habitat in 2000 and $2005 .{ }^{65}$

\section{Section 9-Prohibition of Take}

Once a species is listed as endangered or threatened, Section 9 rigorously protects the species against detrimental activities. Indeed, "[i]f the ESA is the 'pit bull' of environmental regulation, then Section 9

\footnotetext{
59. 16 U.S.C. $\S 1533(b)(3)(A) ; 50$ C.F.R. $\S 424.14$ (a) \& (b).

60. 58 Fed. Reg. 53800 (Oct. 8, 1993).

61. 63 Fed. Reg. 31647 (June 10, 1998); 70 Fed. Reg. 56212 (Sept. 26, 2005),

62. U.S. Fish \& Wildlife Service, Bull Trout Recovery Plan ANd Proposed Critical HABITAT 2, available at www.fws.gov/pacific/bulltrout/PCH_04/Fact\%20Sheets/chapter_23.PDF.

63. 64 Fed. Reg. 41835 (Aug. 2, 1999).

64. U.S. DEP'T OF COMMERCE: NAT'L OCEANIC AND ATMOSPHERIC AdMin.: NAT'L MARINE Fisheries SERVICE, UPDATED STATUS OF FEDERALly Listed ESUs of WEST COAST SALMON AND STEELHEAD 126 (T.P. Good et al. eds., 2005), available at http://swfsc.noaa.gov/publications/fed/ 00749.pdf.

65. 65 Fed. Reg. 52630 (Sept. 2, 2005).
} 
of the ESA is that pit bull's longest and sharpest teeth." ${ }^{\text {"6 }}$ Such teeth are aimed at a broad range of activities that would "take" a listed species, like killing, hunting, and collecting a listed species. ${ }^{67}$ Significantly disturbing a listed species' natural behaviors, such as breeding, feeding, or sheltering, also qualifies as a "take." ${ }^{\text {" }}$ This would include activities that are unrelated to a listed species, but still affect its habitat. ${ }^{69}$ One violation of the ESA take prohibition may cost up to $\$ 25,000$ in civil penalties and up to $\$ 50,000$ and one year in prison for criminal penalties. $^{70}$

\section{Section 10-Habitat Conservation Planning for Non-Federal Parties}

To lessen the bite of Section 9, the ESA allows some limited takings. $^{71}$ Take exceptions are allowed for scientific and conservation efforts, as well as other activities causing incidental takes of small numbers of listed species. ${ }^{72}$ To warrant an incidental take permit, a nonfederal applicant must develop a habitat conservation plan. ${ }^{73}$ Importantly, take exceptions are for incidental harms; consequently, permitted activities cannot endanger the species' very survival. ${ }^{74}$ The Section 10 incidental take provisions have not been a significant piece of the ESA landscape in the Willamette Basin. Rather, the consultation process under Section 7 has been the primary vehicle for incidental take coverage and ESA compliance in the basin.

\section{Section 7-Federal Agency Consultation}

The most significant action under the ESA in the WRB has been the application of Section 7 to the operations of the USACE. Section 7 contains the procedural and substantive requirements that the federal

\footnotetext{
66. SULLINS, supra note 41 , at 39 (internal citation omitted).

67. 16 U.S.C. $\$ \S 1532(19), 1538(a)$.

68. 50 C.F.R. $\S 17.3(\mathrm{c})$.

69. See Palila v. Haw. Dep't of Land \& Natural Res., 852 F.2d 1106, 1108-10 (9th Cir. 1988).

70. 16 U.S.C. $\$ 1540(a)-(b)$.

71. Id. § 1539(a).

72. Id. § 1539(a)(1).

73. Id. $\S 1539(\mathrm{a})(2) ; 50$ C.F.R. $\S 17.3$.

74. H.R. CONF. REP. No. 97-835, at 29 (1982), reprinted in 1982 U.S.C.C.A.N. 2860, 2870 ("This provision establishes a procedure whereby those persons whose actions may affect endangered or threatened species may receive permits for the incidental taking of such species, provided the action will not jeopardize the continued existence of the species.").
} 
government must follow to assist the ESA's goals. ${ }^{75}$ Implementing the regulations for the ESA requires consultation on USACE facilities in the WRB. ${ }^{76}$

After a species is listed under Section 4, the federal government must act to conserve it. ${ }^{77}$ First, all federal agencies must adhere to specific programs to conserve listed species. ${ }^{78}$ Second, federal agencies must assure that their actions do not jeopardize or adversely affect a listed species, a designated critical habitat, a proposed species for listing, nor a proposed critical habitat. ${ }^{79}$ Qualifying agency actions include all activities and programs "authorized, funded, or carried out" by an agency over which that agency has discretionary involvement or control. ${ }^{80}$ Such actions include an agency's authority to grant permits and licenses to third parties and, in the case of the WRB, the ongoing operations of the thirteen federal reservoirs. ${ }^{81}$

The key to Section 7 is that agency actions must not jeopardize listed species or critical habitat. Agencies are expected to assess jeopardy at the earliest possible opportunity ${ }^{82}$ First, agencies inquire whether a species or critical habitat is present within the action area. ${ }^{83}$ Then, if a species or critical habitat is present, agencies may either draft a biological assessment or informally consult with one of the Services. ${ }^{84}$ Each process assesses whether the agency's proposed action is likely to adversely affect listed species or critical habitat. ${ }^{85}$ Should either process suggest that an adverse effect is likely, that Service will formally consult about the proposed action. ${ }^{86}$

In formal consultation, the Service reviews the action's cumulative effects upon the listed species and critical habitat. ${ }^{87}$ From this review, the Service generates a biological opinion that states whether the action

\footnotetext{
75. See SULLINS, supra note 41 , at 60 .

76. 50 C.F.R. $\S \$ 402.01-.16$ (2009).

77. See 16 U.S.C. $\S 1531$ (c)(1) (declaring it to be "the policy of Congress that all Federal departments and agencies" conserve endangered species and threatened species).

78. Id. § 1536(a)(1).

79. Id. § 1536(a)(2), (4).

80. 50 C.F.R. $\S \S 402.02-.03$.

81. 16 U.S.C. $§ 1536(a)(3)$.

82. 50 C.F.R. $\$ 402.14$ (a).

83. Id. § 402.12(c), (d).

84. Id. $\S \S 402.12-.13$.

85. Id. $\S \S 402.12(\mathrm{a}),(\mathrm{k}), 402.13(\mathrm{a}),(\mathrm{b})$.

86. See generally id. $\S 402.14$.

87. Id. $§ 402 \cdot 14(\mathrm{~g})$.
} 
will jeopardize the species or critical habitat. ${ }^{88}$ If the species or critical habitat is likely to be in jeopardy, the Service may suggest reasonable and prudent alternatives that apply minor changes to the proposed action to avoid its adverse effects. ${ }^{89}$ Should the acting agency adopt a reasonable and prudent alternative, the proposed action may proceed. ${ }^{90}$ If jeopardy is likely, but there are no reasonable and prudent alternatives, the acting agency's final option is to seek an exemption from the jeopardy prohibition. ${ }^{91}$ Similar to Section 10 's incidental take permits, the biological opinion may also include an incidental take statement. ${ }^{92}$ As under Section 10, incidental take statements are available if there is some harm to a listed species, but no jeopardy. ${ }^{93}$ Throughout the consultation process, Section 7 prohibits an action agency from becoming overly committed to a proposed action before consultation is complete. $^{94}$ This prohibition helps ensure that the agency is free to adopt a reasonable and prudent alternative should the biological opinion find jeopardy. ${ }^{95}$

Consultation may reinitiate as long as the action agency retains discretionary involvement or control over the action. ${ }^{96}$ A number of situations may prompt re-initiation, including exceeding an incidental take statement, modifying an action beyond the boundaries considered by a biological opinion, risking jeopardy for a newly listed species or critical habitat, or encountering new information that an action is adversely affecting a listed species in a manner not addressed by the biological opinion. ${ }^{97}$

In the WRB, the consultation process for the thirteen federal reservoirs was first initiated in April 2000 and concluded that continued operation of the Willamette Basin Project was likely to adversely affect all four listed species in the basin. ${ }^{98}$ Given the larger dynamics around

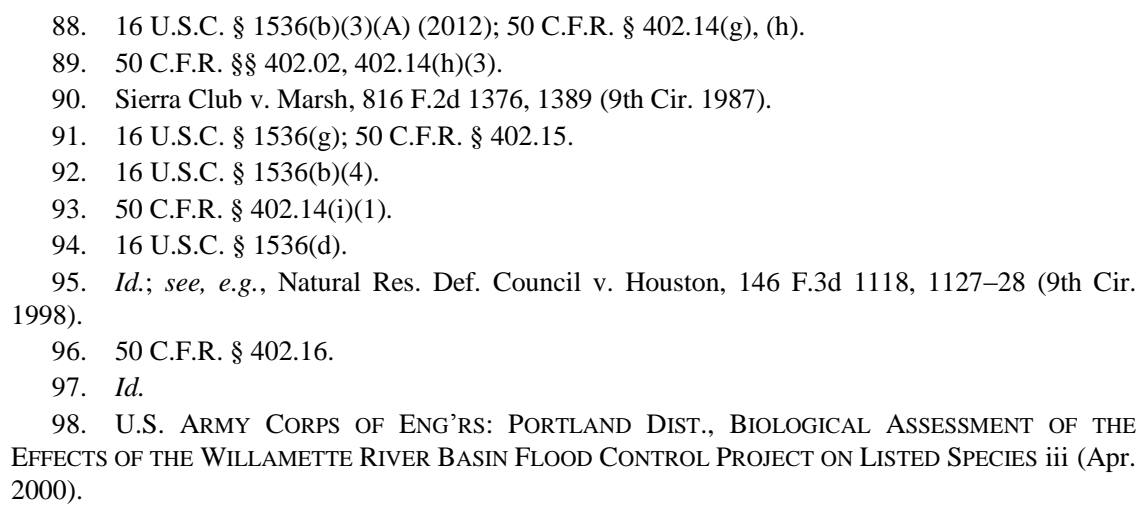

98. U.S. ARMY CORPS of Eng'Rs: PORTLAND Dist., Biological ASSESSMENT of the EFFects of the WillametTe River Basin Flood Control Project on Listed SPeCies iii (Apr. 2000). 
the ongoing consultation on the Federal Columbia River Power System, the consultation on the Willamette Project was delayed. By September 2007, the USACE submitted a revised Biological Assessment, and a coalition of environmental groups filed suit for alleged violations of the ESA. $^{99}$ Ultimately, this lawsuit settled and the parties entered into a consent decree that provided the Section 7 consultation process would be completed and the final Biological Opinion issued by July 2008. ${ }^{100}$ The final Biological Opinion (BO) was released in July 2008, concluding that the continued operation of these thirteen federal reservoirs would jeopardize the continued existence of the four listed fish species. The BO provided a set of reasonable and prudent alternatives and measures that were designed to minimize these adverse effects on the listed species and their critical habitat. These provisions of the BO have a tremendous impact on the management of reservoirs and ultimately affect the flow in the mainstem and the availability of water in the basin.

\section{The Clean Water Act}

In addition to the impact that the federal ESA has had on the basin, the other significant federal statute is the Clean Water Act. With the 1997 amendments to the Federal Water Pollution Control Act of 1972, the modern Clean Water Act (CWA) was born. ${ }^{101}$ While the CWA is a federal statute that delegates significant regulatory oversight to the Environmental Protection Agency (EPA), a federal agency, the CWA also provides that each individual state can play a significant role through an EPA-approved program. ${ }^{102}$ Sections 303 and 302 of the CWA set forth the process that states and the EPA must follow to establish water quality standards. ${ }^{103}$

As states develop and implement these water quality standards, they designate uses for water bodies within the state and then develop water

99. Complaint at 13, Willamette Riverkeeper v. U.S. Army Corps of Eng'rs, No. 07-CV-1399PK (D. Or. Sept. 20, 2007), available at http://www.salmonrecovery.gov/Files/BiologicalOpinions/ Willamette_Complaint.pdf.

100. Stipulation Settlement Agreement and Order of Dismissal, Willamette Riverkeeper v. U.S. Army Corps of Eng'rs, No. 07-CV-1399-PK (D. Or. Feb. 26, 2008), available at http://www.salmonrecovery.gov/Files/BiologicalOpinions/Willamette/Final-Stip-Settlement-Orderof-Dismissal-2-26-08.pdf.

101. 33 U.S.C. $\S 1251-1387$; CWA $§ 101$ et seq.

102. See generally Jeffrey M. Gaba, Federal Supervision of State Water Quality Standards Under the Clean Water Act, 36 Vand. L. Rev. 1167 (1983); Phillip Weinberg \& Kevin A. REILLY, UNDERSTANDING ENVIRONMENTAL LAW 114 (2d ed. 2007).

103. 33 U.S.C. $\S \S 1313(c), 1312$. 
quality criteria to protect these designated uses. ${ }^{104}$ As part of this process the state is required to identify and develop a list of impaired waters, the so-called 303(d) list. ${ }^{105}$ After the state has identified all waters where required pollution controls are not sufficient to attain or maintain the applicable water quality standard, the state is required to establish total maximum daily loads, known as TMDLs, for their waters. ${ }^{106}$ These standards are subject to EPA approval, and, in Oregon, the process of approving these water quality standards has been the subject of ongoing controversy and litigation. ${ }^{107}$ In particular to the Willamette Basin, the question of temperature regulations is significant. It is quite likely that addressing temperature as a water quality standard under the CWA could have an impact on the mainstem flows in the Willamette River.

The sections above discuss three major components of federal law that impact flow in the WRB - the authorizing authorities for the USACE, the Endangered Species Act, and the Clean Water Act as delegated to the State of Oregon by the EPA. Certainly, these are not the only federal laws that impact the Willamette River, but they do serve as the fundamental backbone of the primary dynamics that operate from the federal perspective in the basin. This article turns next to state law and, in a similar fashion, constructs the basic framework at the state law level that affects the Willamette River. Any discussion of state law in the western U.S. necessarily begins with the doctrine of prior appropriation and its impact on the fundamental way that water rights are allocated and regulated by the state.

This discussion naturally includes a brief discussion of the principles of beneficial use and waste, as well as the monitoring and enforcement of water rights. Next, the article turns to the dynamics under Oregon law for transferring water rights. This section closes with a discussion of Oregon law's methods for protecting non-consumptive, instream flow rights.

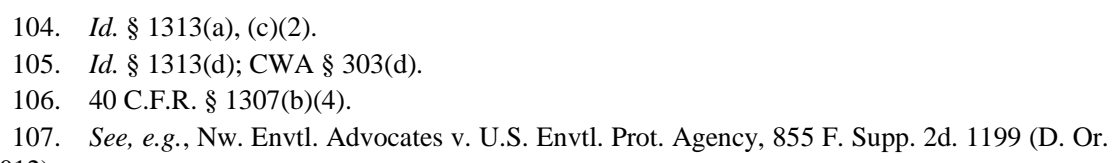




\section{Oregon State Water Law}

\section{Overview of Prior Appropriation}

Oregon's system of allocating rights to surface water and groundwater is based on the prior appropriation system. ${ }^{108}$ This system is commonly described as "first in time, first in right" because each water right issued carries a priority date and the person with the earliest priority date has the most senior right to use water. ${ }^{109}$ Water rights are filled in order of priority when there is not enough water in a stream, and, in cases of shortage, junior water rights holders may not receive any water at all. In Oregon, if two water rights users have the same priority date, those using water for domestic purposes receive water first, followed by those using water for agricultural purposes, and then followed by those using water for manufacturing purposes. ${ }^{110}$ The Willamette River Basin, like all basins in Oregon, operates within the prior appropriation scheme. Thus, any water rights granted by the state in the WRB are exercised in order of their priority. As we examine the dynamics around the flow in the mainstem, it is extremely important to understand the impact of these diversionary rights not only in the mainstem, but also in the tributaries because of their impact on flow.

\section{The Appropriation Process}

Water rights in Oregon are administered through a permit and certification system. A person who wants to obtain a water right files a permit application with the Oregon Water Resources Department (OWRD). ${ }^{11}$ The permit will be granted if the water use is one allowed in that basin by statute, if the water is available for use, if the use will not injure other water rights, and if the proposed use is in the public interest. ${ }^{112}$ With regard to the availability of water, the OWRD must determine if there is in fact available water to be appropriated. Throughout the WRB, there are stream reaches where the OWRD believes there remains unappropriated water; thus, the OWRD would

\footnotetext{
108. OR. REV. STAT. $\$ \S 537.120,537.525$.

109. See, e.g., 94 C.J.S. Waters $\S 402$ (2013) (discussing the "first in time, first in right" system).

110. OR. REV. STAT. $\$ 540.140$.

111. Id

112. Id. § 537.153(1)-(2).
} 
grant new water rights. ${ }^{113}$ This is one of the areas where state and federal law can be in tension. For example, the requirements of the ESA or the CWA may require that much of the unappropriated flow remain instream whereas state water laws may identify that flow as available for appropriation. Understanding the details of how state and federal law interact is key in establishing a law of the river for the WRB. A permit may be issued for less water than requested in the application if the OWRD concludes that the amount requested exceeds the amount that can be beneficially used. ${ }^{114}$

A permit holder has a reasonable time of not more than five years to put the water to beneficial use. ${ }^{115}$ This process may include building diversion canals or installing irrigation systems. Putting a permitted water right to beneficial use "perfects" the water right. The OWRD conducts a survey of the water use and determines whether the right has been perfected to its satisfaction. ${ }^{116}$ After a water right is perfected, the OWRD issues a water rights certificate that gives the certificate holder an actual right to use the water under the certificate for as long as the water is used beneficially. ${ }^{117}$

Not all uses require a permit or certificate, however. ${ }^{118}$ Water for emergency firefighting, fish screens and bypass structures, livestock watering, and the collection of rainwater are examples of some uses exempt from the permitting requirements. ${ }^{119}$ Salmon and trout enhancement projects certified by the State Department of Fish and Wildlife are also exempt. ${ }^{120}$

113. See generally OR. ADMIN. R. 690-502-0010 to -0260 (2014); see also OR. ADMIN. R. 690502-0020(1) (outlining policies for surface water allocation in the basin and referencing future permits in the basin program's objectives); OR. ADMIN. R. 690-502-0030(5), (10) (providing general provisions for permits and applications); OR. ADMIN. R. 690-502-0040(1)-(3), -0040(1) (providing that the specific guidelines for appropriations in each subbasin in OR. ADMIN. R. 690-502-0050 to 0150 "limit access to natural streamflow during periods when the remaining available supplies are insufficient to meet existing water rights and public instream uses 80 percent of the time," thus indicating that streams or tributaries not referenced in the specific guidelines may have remaining water available).

114. OR. REV. STAT. § 537.190(1).

115. Id. §537.230.

116. Id. § 537.250(1); see also Hale v. Water Res. Dep’t, 55 P.3d 497, 500 (Or. Ct. App. 2002).

117. OR. REV. STAT. \$ 537.250(1), (3).

118. Id. $\S 537.141$.

119. Id.

120. Id. §537.142. 


\section{Beneficial Use and Waste}

The basis, the measure, and the limit of water rights in Oregon is the "beneficial use" of the water. ${ }^{121}$ Oregon defines beneficial use as "the reasonably efficient use of water without waste." ${ }^{122}$ Beneficial uses of water under Oregon law include water needed for domestic, municipal, irrigation, power development, industrial, mining, recreation, fish and wildlife uses, and for pollution abatement. ${ }^{123}$ The Water Resources Commission (the Commission) may determine that other uses are beneficial by balancing the benefits of the proposed use against other existing uses, conflicting interests, and other concerns. ${ }^{124}$

Additionally, to meet the requirement of beneficial use, a water user may not "waste" water. ${ }^{125}$ Wasting water results in the forfeiture of the water right. Two ways that a water user may waste water are: (1) using the water in a manner other than the use permitted in the water right itself or (2) failing to use all or part of the water right for five successive years. ${ }^{126}$ If a water user fails to use all or part of their water right for five years, the Commission assumes that the user has wasted the water. ${ }^{127}$

However, there are "non-uses" allowed under Oregon law that are not considered waste. Statutorily excused non-uses include not using water because of a financial hardship, not using water because a government action prevented it, or not using water because it was unavailable. $^{128}$ Additionally, a water user can show that they have facilities capable of receiving the full rate and duty of the water right and were "ready, willing[,] and able" to use the water, but could not use it for some other reason. ${ }^{129}$ The Oregon legislature created that exception to prevent water users from diverting unneeded water for the sole purpose of avoiding losing their water right.

\footnotetext{
121. Id. $\S \S 537.120,540.610(1)$; see also Janet C. Neuman, supra note 10, at 920.

122. OR. ADMIN. R. 690-300-0010(5) (2008).

123. OR. REv. STAT. § 536.300(1); see also OR. ADMIN. R. 690-300-0010 (supplying specific definitions for each type of use).

124. See Benz v. Water Res. Comm'n, 764 P.2d 594, 597 (Or. Ct. App. 1988).

125. OR. ADMIN. R. 690-300-0010(5).

126. OR. Rev. StAT. § 540.610(1); see also Staats v. Newman, 988 P.2d 439, 442 (Or. Ct. App. 1999).

127. OR. REV. STAT. § 540.610(1).

128. Id. §540.610(2).

129. Id. §540.610(3).
} 


\section{E. Water Measurement, Monitoring, and Enforcement}

The dynamics around the regulation of beneficial use and waste, particularly the willingness of the state to enforce or the availability of the necessary data to support the state in enforcing these provisions of state law, are key in a basin with the demands on water. As demands for water in the basin increase in the future, the doctrine of prior appropriation provides a mechanism, through the definition of beneficial use and waste, which both protects the actual use of water and ensures that the maximum amount is available for other important purposes as well. This is one of the ways that state water law has within its existing structure the flexibility and discretionary authority to address changing needs and demands in the WRB, as well as other basins throughout the state and the western U.S. One of the goals of the WW 2100 project is to model where these potential scarcities may exist or arise in the WRB in the future so that we can explore the use of the inherent flexibility of the law to proactively address these problems.

\section{Oregon's Water Measurement Strategy}

Water measurement can be an important tool for managing water resources in the WRB. In Oregon, the OWRD and the Commission have authority to measure water use by conditioning new permits or by requiring measurement on existing uses. ${ }^{130}$ However, only a relatively small portion of water diversion throughout Oregon, including the Willamette Basin, is currently being measured. As the demands on water in the WRB increase, the importance of measurement and the availability of this data become increasingly important.

Oregon's existing water measurement regulatory framework is covered under a patchwork of statutes. Under Section 537.099(1) of the Oregon Revised Statutes, all governmental entities with a water right are required to measure and report their water use annually to the OWRD. Governmental entities include federal and state agencies, local governments, irrigation districts, and water control districts. ${ }^{131}$ The statute requires the report to include "the amount of water used by the governmental entity, the period of use and the categories of beneficial use to which the water is applied." 132 Under Section 537.211 of the

\footnotetext{
130. Amos, supra note 9, at 60 .

131. OR. REV. STAT. § 537.099(2).

132. Id. § 537.099(1).
} 
Oregon Revised Statutes, the OWRD maintains the authority to condition issuance of any new water right permit. "The permit shall specify the details of the authorized use and shall set forth any terms, limitations and conditions as the department considers appropriate," including installation of a water measurement device. ${ }^{133}$ The OWRD may impose measurement conditions on a new permit if "an application discloses the probability of wasteful use or undue interference with existing wells or ... [interferes with] existing rights to appropriate surface water." ${ }^{134}$ If the Commission and OWRD do not include measuring requirements when they issue a permit, they still maintain the authority to require measurement. ${ }^{135}$ Under Section 540.310(2), the Commission may require a water ditch or canal owner to place suitable measuring devices along the ditch or canal and may require the owner to report the measurements according to a Commission-established schedule. ${ }^{136}$

Under Section 540.330(1), the Commission can also require the owner or manager of a reservoir located in the flow of a natural stream to place measuring devices above and below the reservoir on each natural stream or water source that discharges into the reservoir. Finally:

[I]n addition to any other authority of the Water Resources Commission to order installation of a measuring device, if the commission finds accurate water use information necessary because of serious water management problems created by groundwater decline, unresolved user disputes, or frequent water shortages, then the commission by rule may require a water-right owner using any surface or ground water sources within the state to install a totalizing measuring device and to submit annually a water-use report. ${ }^{137}$

However, before issuing such an order, the Commission must hold a hearing in the affected area to determine if a major management problem exists and allow any affected person the opportunity to present alternative methods or devices that may solve the management problem. ${ }^{138}$

Despite measurement requirements, the OWRD does not require many users to report their measurements. ${ }^{139}$ The OWRD estimates there

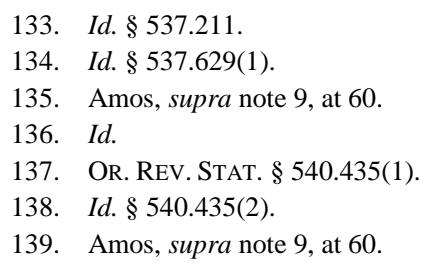


are currently 75,000 existing surface water points of diversion, about 23,000 ground water points of appropriation, approximately 24,000 reservoirs, 4,000 ground water registrations, and around 230,000 exempt groundwater diversions. ${ }^{140}$ Currently, only about ten percent of these water users' permits require them to report, representing nearly fifty percent of the state's water usage. ${ }^{141}$

In 2000, the Oregon Water Resources Commission developed a strategy for improving water measurement statewide, focusing on diversions that have the greatest impact on streamflows in areas with the greatest needs for fish. ${ }^{142}$ The OWRD, in concert with the ODFW, developed a statewide inventory of significant diversions within highpriority watersheds across the state with the intent to increase measurement at these diversions. ${ }^{143}$ These high-priority watersheds are known as Priority Water Availability Basins or Priority WABs. The result of the effort combines an assessment from the ODFW of the potential for fish restoration and an assessment from the OWRD of the potential for flow restoration. ${ }^{144}$ Significant diversions are defined as diversions that reside within Priority WABs and: (1) surface water diversions that are required by OWRD to measure and report through a water-right condition; or (2) surface water diversions without a measurement condition in the water right that are (a) greater than five cubic feet per second (cfs); or (b) greater than ten percent of the lowest monthly fifty percent exceedance flow as defined in the water availability model and greater than $0.25 \mathrm{cfs} .{ }^{145}$

Regarding the status of this water measurement framework in the Willamette Basin, the OWRD reported to the Commission on March 9, 2007 on measurement activities in priority watersheds including the Willamette Basin. ${ }^{146}$ In accordance with the Strategic Measurement Plan, the OWRD has identified 134 significant diversions within seventeen priority watersheds in the Willamette Basin. ${ }^{147}$ As of March

\footnotetext{
140. Id.

141. Or. Water Res. Dep'T, Annual Performance Progress Report (APPR) FOr Fiscal YEAR (2012-2013) 30 (2013), available at http://www.oregon.gov/owrd/law/docs/owrd_annual _pm_report_2013.pdf.

142. Or. Water Res. Dep'T, Strategic Measurement Plan 1 (2007), available at http://www.oregon.gov/owrd/docs/reports/priority_wab_report03-2007pg1-16.pdf.

143. Id.

144. Id.

145. Id.

146. Id. at 13 .

147. Id.
} 
2007 , about $44 \%$ of these significant diversions were being monitored, with fifty-nine measurement devices in place. ${ }^{148}$

\section{Water Right Monitoring and Enforcement}

The OWRD's Field Services Division performs most water quantity monitoring and enforcement in Oregon. ${ }^{149}$ The OWRD has divided the state into five field regions and twenty-one districts. ${ }^{150}$ In each district, the watermaster, an OWRD-appointed officer, manages water use with the help of an assistant and a number of water resources technicians, including well inspectors, water right inspectors, water restoration specialists, and hydrotechnicians. ${ }^{151}$ Watermaster duties are defined under Section 540.045 of the Oregon Revised Statutes and include various methods of distributing water "in accordance with ... existing water rights" as well as any other duties delegated or required by the Water Resources Director. ${ }^{152}$

The first step of water rights enforcement is regulating the distribution of surface water. Watermasters and their field staff frequently measure streamflow throughout their districts on site to monitor instream water rights or minimum streamflow requirements. If the flow is inadequate to satisfy all instream water rights, the minimum flow requirements, or if other entities complain that their water right allocations are not being met, the watermaster begins an investigation. ${ }^{153}$ If the investigation was triggered by user complaint, it frequently involves measuring streamflow at the point of diversion for the water right not being met, searching for illegal uses, and generating a list of junior users. ${ }^{154}$ Based on this investigation, the watermaster decides on the appropriate action. In this stage of enforcement, actions take the form of informal requests to curtail water use, either through personal contact or letters. ${ }^{155}$

Watermasters will first address illegal uses of water. An illegal use

148. Id

149. Rick Bastasch, The Oregon Water Handbook: A Guide to Water and Water MANAGEMENT 148 (2006).

150. OR. WATER RES. DEP'T, WATER RIGHTS IN OREGON: AN INTRODUCTION TO OREGON'S WATER LAWS 42-43 (2013).

151. BASTASCH, supra note 149, at 147-48; OR. REV. STAT. § 540.020(1) (1985).

152. OR. REV. STAT. $\$ 540.045(1)$.

153. Id.

154. Id.

155. BASTASCH, supra note 149 , at 148. 
is any unauthorized use of water: use without a water right, use in greater amounts than authorized, use in violation of terms or conditions of a permit or certificate, or use after having been cut off. ${ }^{156}$ If the flow is still inadequate to satisfy the senior water right, watermasters will begin to regulate junior users. ${ }^{157}$ However, if the watermaster determines that an inadequate amount or none of the water resulting from cutting off a junior user would reach the senior user, the watermaster may disregard the complaint as a "futile call." 158 Watermasters may also regulate illegal uses that they discover or have been told about. ${ }^{159}$

If users do not voluntarily comply with watermaster requests, watermasters may engage in the formal enforcement process. Watermasters, as deputies of the Water Resources Director, have the authority to enter onto any private property in the performance of their duties. ${ }^{160}$ A watermaster may then take control of the waterworks at the point of diversion and physically shut off the user after posting a signed notice "setting forth that the headgate, valve or other control works has been properly regulated and is wholly under the control of the watermaster." 161

In 2011, watermasters and their assistants reported a total of 8,137 regulatory actions, 1,599 of which were formal written actions, on 361 stream systems. ${ }^{162}$ Of these, 249 actions were taken to protect instream rights, 151 to protect senior rights, and 97 to stop illegal uses. ${ }^{163}$

\section{F. Transferring Water Rights in Oregon}

\section{Overview of Water Transfers}

Today, virtually all of Oregon's surface water has been appropriated with some remaining water available in the mainstem of the Willamette and in the McKenzie River. ${ }^{164}$ A water right holder's ability to transfer

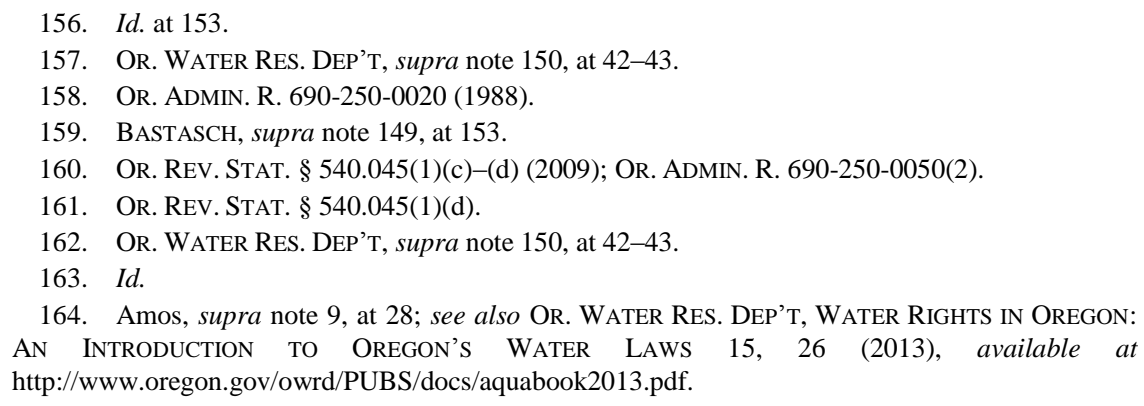


existing water rights can alleviate the challenges associated with the lack of available water for appropriation and changing water demands in the prior appropriation system. ${ }^{165}$ As society's demands and needs for water change, this is another authority within state water to address these changing preferences within the context of existing law.

Under a water right, use of water must conform to the place of use, point of diversion, and type of use specified in the water permit. ${ }^{166}$ It cannot be used for any other purpose than what is specified in the water right. However, if a right holder wishes to use water for a different purpose than what the water right certificate allows, use the water in another location, or divert the water from a different spot, the right holder can file a transfer application with the Water Resources Department to seek approval for the change. ${ }^{167}$

Oregon Revised Statutes chapter 540 provides the requirements and process for transferring a water right. Only certain rights may be transferred. Specifically, transfer is allowed only for those rights that have been adjudicated and received a court decree, that have a water right certificate or a permit, or where the OWRD has approved a previous transfer and satisfactory proof of completion has been filed with the Commission. ${ }^{168}$ A water right holder may apply for a permanent or temporary transfer; the OWRD will grant a temporary transfer for a period no longer than five years. ${ }^{169}$ Water users may also transfer all or a portion of their rights for instream uses. ${ }^{170}$ These transfers may be either permanent or temporary, but they require showing that there will be no injury to other water right holders. ${ }^{171}$

\section{Permanent Transfers}

An applicant seeking a permanent transfer of a water right must provide information to the OWRD so that it may determine compliance with Oregon prior appropriation law. ${ }^{172}$ Among other basic information, the applicant must describe the current use of the water, the proposed use 
of the water, and the reasons for the change. ${ }^{173}$ Furthermore, the applicant must provide evidence that the water has been used in a manner consistent with the water right for the past five years. ${ }^{174}$ In other words, the applicant must show that the water right is not subject to forfeiture.

To approve a permanent transfer application, the OWRD must conclude that the proposed change will not injure other water rights. To assist in this decision, an applicant must publish notice of the proposed change in a newspaper within the area where the water rights are located. ${ }^{175}$ This puts the public on notice and allows other water rights holders to come forward to comment and file protests against the approval of the application. ${ }^{176}$ The OWRD then has a hearing to determine whether the transfer would injure other users. ${ }^{177}$ While the OWRD is making its decision, the water may be used according to the current water right until the transfer is approved. ${ }^{178}$

There are a few activities exempt from the application requirements under Oregon law. For instance, applications are not required for transfers of irrigation rights where the right holder seeks to transfer use of the water to other activities related to irrigation. ${ }^{179}$ This is allowed so long as there is no other change in use, such as increases in the amount, acreage irrigated, or season of use. ${ }^{180}$ Additionally, industrial uses that meet certain qualifications may change the use of water without applying to the OWRD. ${ }^{181}$

\section{Temporary Transfers}

A water rights holder may temporarily change a water right's place of use to allow a right attached to a specific parcel of land to be used on another parcel. These temporary transfers may not last longer than five years. ${ }^{182}$ After the five-year period concludes, the transferred water use will revert back to the original use. ${ }^{183}$ However, there is no statutory

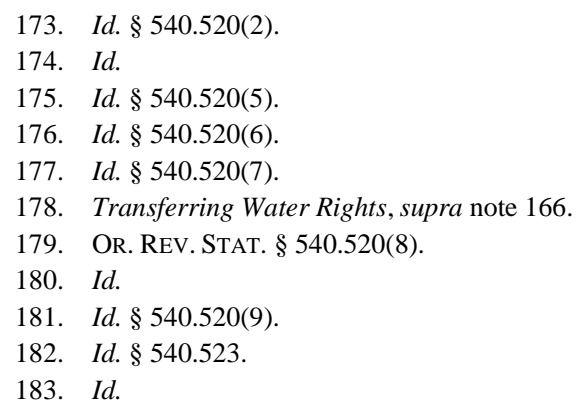


restriction on the amount of times the OWRD may re-approve applications for the same temporary transfer in successive terms.

\section{Groundwater Transfers}

A surface water user may also transfer her point of diversion to appropriate groundwater. ${ }^{184}$ However, the OWRD must find that: (1) the aquifer is hydraulically connected to the surface water; (2) the change will not result in enlargement or injury to existing water rights; (3) the change will affect the surface water the same as the authorized use; and (4) the proposed groundwater use is located within 500 feet of the surface water, and when the surface water is a stream, that the use is also located within 1,000 feet upstream or downstream of the original point of diversion. ${ }^{185}$

\section{G. Protecting Non-Consumptive Uses of Water in Oregon: Instream Flow Rights and the Conserved Water Program}

In the western U.S. one of the most profound changes in the prior appropriation doctrine in the last fifty years has been the recognition of a state-based water right for non-consumptive instream flow use. The recognition of instream flow as a beneficial use represents a tremendous mechanism in state law for managing flow in the mainstem of the Willamette River.

\section{Instream Flow Rights}

Under the prior appropriation model, traditional water rights require that water be diverted to qualify as beneficial use. Without more, this requirement precludes water remaining in a stream from satisfying other uses, such as fish flows or recreational activities. Over time, western states have recognized beneficial use without requiring a diversion. One such non-consumptive use is instream flow, a legal concept that recognizes the value of maintaining water within a stream for certain purposes. Essentially, the recognition of instream flow rights allows water to remain in a stream instead of requiring diversion and out-ofstream use.

In 1987, Oregon was the first state to recognize instream flow as a

184. Id. §540.531(1).

185. Id. $\$ 540.531(2)(\mathrm{a})$. 
beneficial use. ${ }^{186}$ Oregon's instream conservation laws have evolved by allowing for non-consumptive uses in favor of the public interest. In 1915, the Oregon legislature precluded appropriation for twenty-three streams and waterfalls along the highway in the Columbia River Gorge to protect their scenic attributes. ${ }^{187}$ In 1955 , the legislature established the State Water Resources Board, charged with formulating a water resources program for the state. ${ }^{188}$ The charge included that " $[\mathrm{t}] \mathrm{he}$ maintenance of minimum perennial stream flows sufficient to support aquatic life and to minimize pollution shall be fostered and encouraged if existing rights and priorities under existing laws will permit." ${ }^{189}$ By adopting these minimum stream flows, the legislature expanded Oregon's ability to use an instream flow regime to support aquatic life, minimize pollution, and maintain recreational opportunities. ${ }^{190}$ However, at the time, the fact that these minimum flows were administrative rules and not recognized as full water rights severely limited their efficacy in protecting instream uses. ${ }^{191}$

Finally, in 1987, the Oregon legislature passed the Instream Water Rights Act (the Act), codified in chapter 537 of Oregon Revised Statutes, to protect and promote instream uses of water. ${ }^{192}$ Unlike private out-ofstream applications of water, like agricultural, municipal, or industrial uses, the OWRD holds instream rights in trust, and the water remains in its natural stream for public use and benefit. ${ }^{193}$ The Act specifically recognized four instream water uses for public benefit as beneficial uses: (1) recreation; (2) pollution abatement; (3) navigation; and (4) "conservation, maintenance, and enhancement of aquatic and fish life, wildlife, fish and wildlife habitat and other ecological values." 194 The

186. Sandi Zellmer, Legal Tools for Instream Flow Protection, in INTEGRATED APPROACHES TO Riverine Resource Stewardship: Case Studies, Science, Law, People, and Policy 285 (2008).

187. Janet C. Neuman, The Good, the Bad, and the Ugly: The First Ten Years of the Oregon Water Trust, 83 NeB. L. REV. 432, 438 (2004).

188. Neuman et al., supra note 7, at 1139-40.

189. Id.

190. Id.

191. Id. at $1144-48$.

192. In-stream Water Rights Act, OR. REV. STAT. §§ 537.332-360 (2013); Obtaining New Water Rights, OR. WATER RES. DEP'T, http://www.oregon.gov/owrd/pages/pubs/aquabook_new rights.aspx (last visited Feb. 14, 2014).

193. OR. ReV. STAT. § 537.332(3); Amos, supra note 9, at 65.

194. Amos, supra note 9, at 65; OR. REv. STAT. § 537.332(5); see also OR. ADMIN R. 690-0770000(3) (2008); OR. REV. STAT. § 537.332(3) (stating that “'[i]n-stream water right' means a water right held in trust by the Water Resources Department for the benefit of the people of the State of Oregon to maintain water in-stream for public use"); OR. REV. STAT. § 536.310(1) (stating 
Act further converted any prior established minimum perennial stream flows to actual water rights vested exclusively in the OWRD and retaining their original priority date. ${ }^{195}$ The OWRD is the only entity that may hold instream flow rights, and these rights are held in trust for the people of Oregon. ${ }^{196}$ The OWRD holds and enforces instream flow rights as any other appropriator in the line of priority, but gets to set the minimum level of instream flow. ${ }^{197}$ Nevertheless, in a Governordeclared drought, the Act allows the OWRD to give preference to human consumption and livestock watering over other uses, including instream uses. ${ }^{198}$

In Oregon, the amount of water reserved as "in-stream flow" is defined as "the minimum quantity of water necessary to support the public use requested by an agency." 199 When natural stream flows are the source for meeting instream water rights, the amount allowed for the water right cannot exceed the estimated average natural flow. ${ }^{200}$ Instream flows are measured in cubic feet per second (cfs) along the stretch of stream or river. ${ }^{201}$ Although instream flows do not ensure that

"[e]xisting rights, established duties of water, and relative priorities concerning the use of the waters of this state and the laws governing the same are to be protected and preserved subject to the principle that all of the waters within this state belong to the public for use by the people for beneficial purposes without waste" (emphasis added)); OR. REV. STAT. § 537.334(1) (stating "[p]ublic uses are beneficial uses"; instream flow is a public use); see also OR. REV. STAT. § $540.610(2)(n)$ (nonuse during a time when the water right was leased as an in-stream right does not subject the right to forfeiture).

195. OR. REV. STAT. $\$ 537.346$. There is ongoing discussion regarding the conversion of the majority of the minimum perennial streamflows from the mainstem of the Willamette River because only a small portion was actually converted to instream flow rights as directed by the 1987 Act. The remainder was recognized as storage rights in the reservoirs on the Willamette system. As the Willamette Basin faces increased pressure on supply, the question of the conversion of these storage rights to live flow rights will need to be addressed. This is yet another area where state and federal law will interact. If the CWA or the ESA require increased flows, these unconverted instream water rights could help to satisfy that demand.

196. Id. $\$ 537.332(3)$.

197. Id. $\$ 537.346$.

198. Obtaining New Water Rights, supra note 192.

199. OR. REV. STAT. $\$ 537.332(2)$.

200. OR. ADMIN. R. 690-077-0015(4) (2013) ("If natural streamflow or natural lake levels are the source for meeting instream water rights, the amount allowed during any identified time period for the water right shall not exceed the estimated average natural flow . . .."). The estimated average natural flow means "average natural flow estimates derived from watermaster distribution records, Department measurement records and application of appropriate available scientific and hydrologic technology." OR. ADMIN. R. 690-077-0010(10).

201. OR. ADMIN. R. 690-077-0015(7)-(8). While out-of-stream rights only require measurement at the point of diversion, instream water rights require measurement at several points along the affected stream. OR. ADMIN. R. 690-250-0030. Instream flow rights can be measured by a point or reach, but reach is preferred. OR. ADMIN. R. 690-077-0015(6)-(7). 
certain quantities of water are always present in a stream, the OWRD can require junior water rights holders to stop diverting water to satisfy the minimum instream levels. ${ }^{202}$ Nevertheless, instream flow rights may not injure water rights holders with more senior priority dates. ${ }^{203}$

Instream flow rights in Oregon can be achieved through new appropriation, transfers, or leases. ${ }^{204}$ Under the Act, only state environmental agencies may apply to the OWRD for new appropriations of instream flow rights. ${ }^{205}$ Namely, the Department of Fish and Wildlife, the Department of Environmental Quality, and the Department of Parks and Recreation can apply for minimum instream flow rights to support habitat, pollution abatement, and scenic and recreational values, respectively. ${ }^{206}$

Any individual water rights holder may voluntarily convert their water rights to an instream flow right and then must transfer it to the OWRD to hold in trust for the people of Oregon. ${ }^{207}$ Oregon's current law provides that "[a]ny person may purchase or lease all or a portion of an existing water right or accept a gift of all or a portion of an existing water right for conversion to an instream water right." ${ }^{208}$ Any water right that is converted to an instream water right retains the priority date of the water right purchased. ${ }^{209}$

In addition to permanent transfers, holders of water rights may lease their rights for instream use through a temporary transfer or lease. ${ }^{210}$ The option of leasing water rights to instream rights can provide water rights holders a mechanism to prevent loss of their rights by forfeiture. ${ }^{211}$ Water rights in Oregon are generally subject to forfeiture after five years of non-use. However, by temporarily leasing unused water rights to the OWRD, water rights holders sidestep the "use it or lose it" appropriation model by retaining their underlying right to the water so long as they maintain their diversion capabilities. ${ }^{212}$ Instream leases cannot last

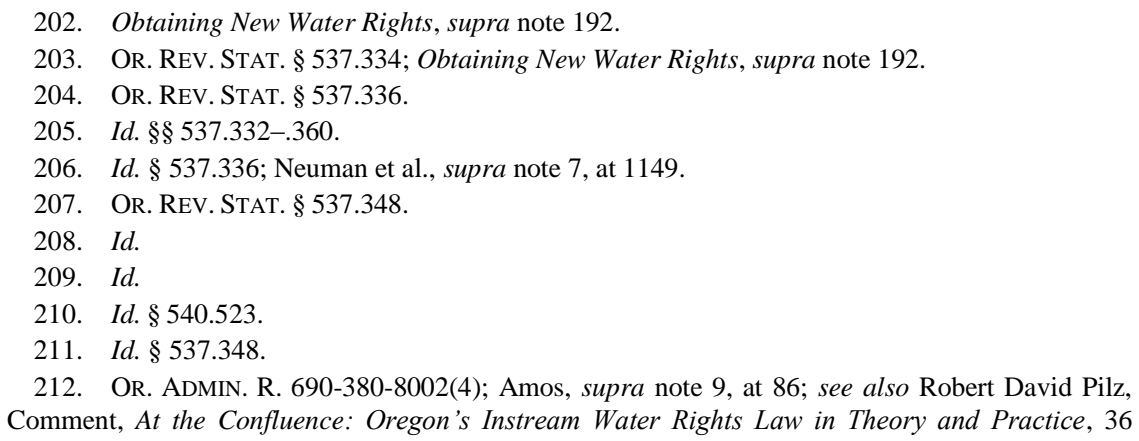


longer than five years - or five irrigation seasons for irrigation rightsthough leases may have unlimited renewability. ${ }^{213}$ The most significant limitation to the transfer of water to instream uses is that the transfer must not injure other existing water rights. ${ }^{214}$ The OWRD will not approve a transfer unless it makes an affirmative finding that the transfer would not injure any existing rights. ${ }^{215}$

Oregon's State Scenic Waterways Act (SSWA) provides an additional safeguard for the instream flow of water. The SSWA mandates that " $[\mathrm{t}] \mathrm{he}$ free-flowing character of [the designated] waters shall be maintained in quantities necessary for recreation, fish and wildlife uses" consistent with the statute. ${ }^{216}$ The Oregon Supreme Court decision in Diack v. City of Portland prohibited uses of water upstream from a designated State Scenic Waterway that would adversely affect the free-flowing qualities of the designated water. ${ }^{217}$ The Diack decision augmented the strategic value of the location of State Scenic Waterway designations on a stretch of river. ${ }^{218}$ Prior to Diack, the Water Resources Commission limited its application of the SSWA to diversions proposed within a designated stretch of water. ${ }^{219}$ Diack clarified that the Water Resources Commission must conform decisions on proposed appropriations to the scenic waterways values of the SSWA. ${ }^{220}$ Furthermore, the court's decision mandated that the Water Resources Commission must consider whether each proposed diversion upstream of a scenic waterway "is necessary to" the uses specified in the SSWA. ${ }^{221}$

\section{Conserved Water Program}

Oregon's Allocation of Conserved Water Program (the Program) allows any water user who conserves water to use a portion of the conserved water on additional lands, to lease or sell the water, or to

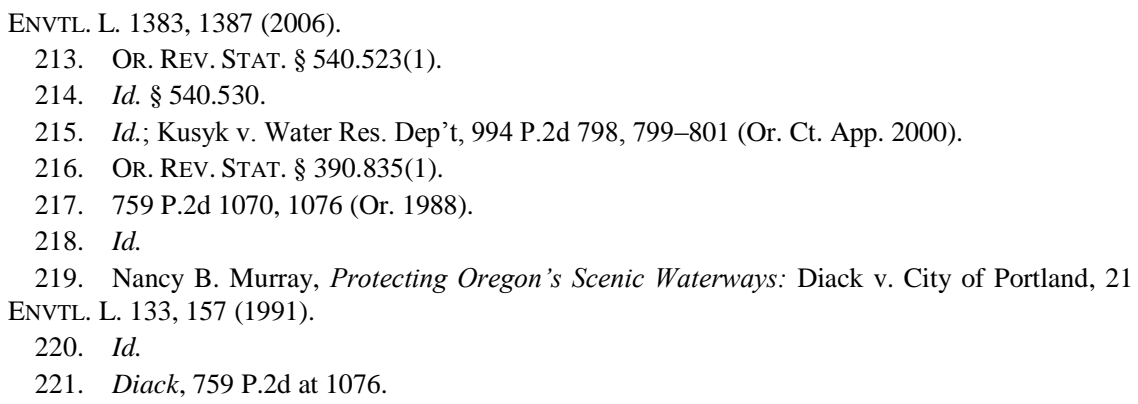


dedicate the water to instream use. ${ }^{222}$ By allowing water use on additional lands and for new uses of water, the Program provides water users an economic return on conservation investments. ${ }^{23}$ When water right holders undertake conservation measures and apply to the Program, they must convert a portion of the conserved water into an instream right. ${ }^{224}$ In exchange, the OWRD grants the right holder greater latitude in how they use the remaining portion of conserved water. ${ }^{225}$

The Oregon legislature originally passed statutes authorizing the Program in 1987 and amended them in 1993. Statutes and administrative rules associated with Oregon's Conserved Water Program can be found in Oregon Revised Statutes sections 537.455 to 537.500 and Oregon Administrative Rule 690.18. The statutes define "conservation" as "the reduction of the amount of water diverted to satisfy an existing beneficial use achieved either by improving the technology or method for diverting, transporting, applying or recovering the water or by implementing other approved conservation measures." 226 The Conserved Water statute provides fundamental requirements and restrictions for water conserved under the Program. As a baseline requirement, any application for conserved water must be filed within five years of the date the conservation measures were implemented. ${ }^{227}$

Similar to the instream water transfer mechanism, the Conserved Water Program creates an opportunity to voluntarily establish instream water rights from preexisting rights with no loss of priority. ${ }^{228}$ Allocations of conserved water may retain the original priority date of the source water right or be assigned a priority date one minute later. ${ }^{229}$ An allocation's assigned priority date is the same for both the applicant and the state. ${ }^{230}$ Allocations that are not assigned to the state may be leased to instream use pending a final allocation to another use and shall

222. Allocation of Conserved Water, OR. WATER RES. DEP'T, www.oregon.gov/owrd/pages/mgmt_conserved_water.aspx (last visited Mar. 29, 2014); see also Neuman et al., supra note 7, at 1150 .

223. Allocation of Conserved Water, supra note 222.

224. Amos, supra note 9, at 90.

225. Id.

226. See generally Allocation of Conserved Water, supra note 222 (describing the purpose and implementation of the program).

227. OR. REV. STAT. § 537.465(1)(b) (2008).

228. Amos, supra note 9, at 90.

229. OR. REV. STAT. § 537.485(1).

230. Id. § 537.485(2). 
not be subject to forfeiture if so leased. ${ }^{231}$

The Program is administered by the OWRD. When a user files an application for allocation of conserved water, the OWRD determines the quantity of water conserved and may reduce that quantity to "mitigate the effect of other water rights." 232 When any allocation of conserved water is made, the state will retain at least twenty-five percent of the conserved water. ${ }^{233}$ The state then allocates seventy-five percent of the water right to the user and converts the remaining twenty-five percent into an instream right held in trust by the state. ${ }^{234}$ If the OWRD determines that the conserved water is necessary to support instream flow purposes, it will convert the water to an instream water right. ${ }^{235}$ However, if the state or federal government provides more than twentyfive percent of the financing for the conservation project and that money is not subject to repayment, the state will convert the same percentage into an instream right. ${ }^{236}$

Despite this instream provision, an applicant may always voluntarily retain up to twenty-five percent of the conserved water, even if the project is entirely publically funded. ${ }^{237}$ After completing the allocation of conserved water, new certificates are provided for the remaining portion of the originating right as well as new rights covering the allocated water. ${ }^{238}$ An applicant may also voluntarily convert the entire amount of conserved water to be held in trust by the state as an instream right. Furthermore, the OWRD may determine that additional instream flow is not necessary to support established in-river purposes, in which case that portion will revert to the public and be made available for future appropriation. ${ }^{239}$ A user must file an application for conserved water within five years of the date from which the conservation measures were first implemented. ${ }^{240}$

231. Id. $\S \S 537.490(1), 537.500(1)$; BRUCE AylWard, RESTORING WATER CONSERVATION SAVINGS to OREGON RIVERS: A REVIEW OF OREGON'S CONSERVED WATER STATUTE: REPORT tO NATIONAL FISH \& WILDLIFE FOUNDATION 6 (2008), available at http://www.ecosystemeconomics .com/Resources_files/Aylward\%20(2008)\%20Oregon's\%20Conserved\%20Water\%20Program.pdf.

232. See Amos, supra note 9, at 90.

233. OR. REV. STAT. § 537.470(3).

234. Id.

235. Id

236. See Amos, supra note 9, at 90.

237. OR. REV. STAT. § 537.470(3).

238. Id. § 537.470(6).

239. Id. § 537.470(3).

240. See Amos, supra note 9, at 90. 
Under the Conserved Water Program, the priority date of the new water right certificate does not change. A new water right certificate with the original priority date is issued reflecting the reduced quantity of water being issued with the improved technology. ${ }^{241}$ Other certificates are issued for the applicant's portion of the conserved water and for the state's instream water rights. The priority dates of these certificates are either the same as the original water right or junior by one minute. It is up to the applicant to decide which priority date they want to establish for the conserved water. ${ }^{242}$

As we move to better understanding the dynamics of water scarcity in the Willamette River Basin over the next decade, tools like Oregon's instream flow law and the Conserved Water Program will be important for adapting to changing circumstances. These programs represent the kind of flexibility and adaptability that state law can offer, and these tools are within the existing legal infrastructure in the State of Oregon. The questions become how, when, and to what extent we are willing to deploy the tools we have at hand.

\section{EVAlUating THE FUTURE IN THE WILlaMETte RIVER BASIN USING EXISTING LEGAL INFRASTRUCTURE}

Based on the basic legal framework described above for federal and state law, the WW 2100 project and follow-up projects hope to develop systematic applications of modeling approaches to expressly address the conflicts and flexibilities inherent in western water law in the face of climate and population change-driven water scarcity. In previous efforts using Envision, including WW 2100, researchers have coupled state-ofthe art hydrological, ecological, and socio-economic models within a single framework, operating over a hundred-year time frame. As a result, the WW 2100 efforts, and hopefully future research, can now simulate alternative land and water use scenarios at unprecedented levels of detail and periods of time, including individual water rights and individually-owned parcels of land, and at the daily time steps relevant to the hydrologic implications of climate change. One proposed second phase of this work, if funded, seeks to use this agent-based modeling, as opposed to the economic modeling platform of the WW 2100, to delve more thoroughly into the particular dynamics of federal and state water

241. See Allocation of Conserved Water, supra note 222.

242. Id. 
law and policy by investigating and evaluating how water scarcity outcomes might be different depending on what alternative future assumptions are made about legal flexibility and adaptability. Similar efforts to look at changes to state and federal water law policy are also integral to the final stages of the work on the WW 2100 project. The legal components of both projects, as well as future research, add a new dimension to the integration of biophysical parameters and social science data by bringing legal research regarding the interaction of state and federal water law, on issues like instream flow and water quality, to bear on adaptation and resilience strategies. All of the proposed projects are designed to bring value to stakeholders and agency actors by identifying the existing flexibility within the state and federal legal and policy frameworks that can be responsive to anticipated changes. Once these flexibilities are represented, they will facilitate the investigation of the resiliency and adaptive capacity inherent within the current legal system and identify where changes to law and policy might be most effective. Results will include the identification of where existing law, federal or state, may lack the flexibility needed to meet anticipated future challenges.

Through the integration of legal issues with the work of the various research teams, we hope to integrate Envision's anticipatory modeling capacity with an in-depth treatment of the combined state and federal water law framework ("the Law of the Willamette River") to explore the impact and inter-relationship of the fragmented regulatory and jurisdictional structure on future scenarios for the basin. Further, the legal components of this work will identify the flexibilities that state and federal law provide to address the changing circumstances in this basin and other basins that are governed by prior appropriation and experience the same overlay of federal law. Ultimately, by fully exploring the state and federal spheres of regulatory and legal authority, we will identify the ways that state and federal law interact with each other and identify sources of resilience and flexibility inherent in the legal framework. We will explore the boundaries of legal and policy responses to projected future climate and population change to identify instances when and where this flexibility will, in turn, allow policy makers to respond to changing conditions to ameliorate water scarcity and provide a detailed understanding of the full range of legal and policy options that are available for the process of adapting to changed conditions. 
The diagram below shows how the projects seek to integrate law and policy change into the larger Envision-based models-one version employing an economic model and the other employing agent-based modeling with the role of law and policy reflected in each.

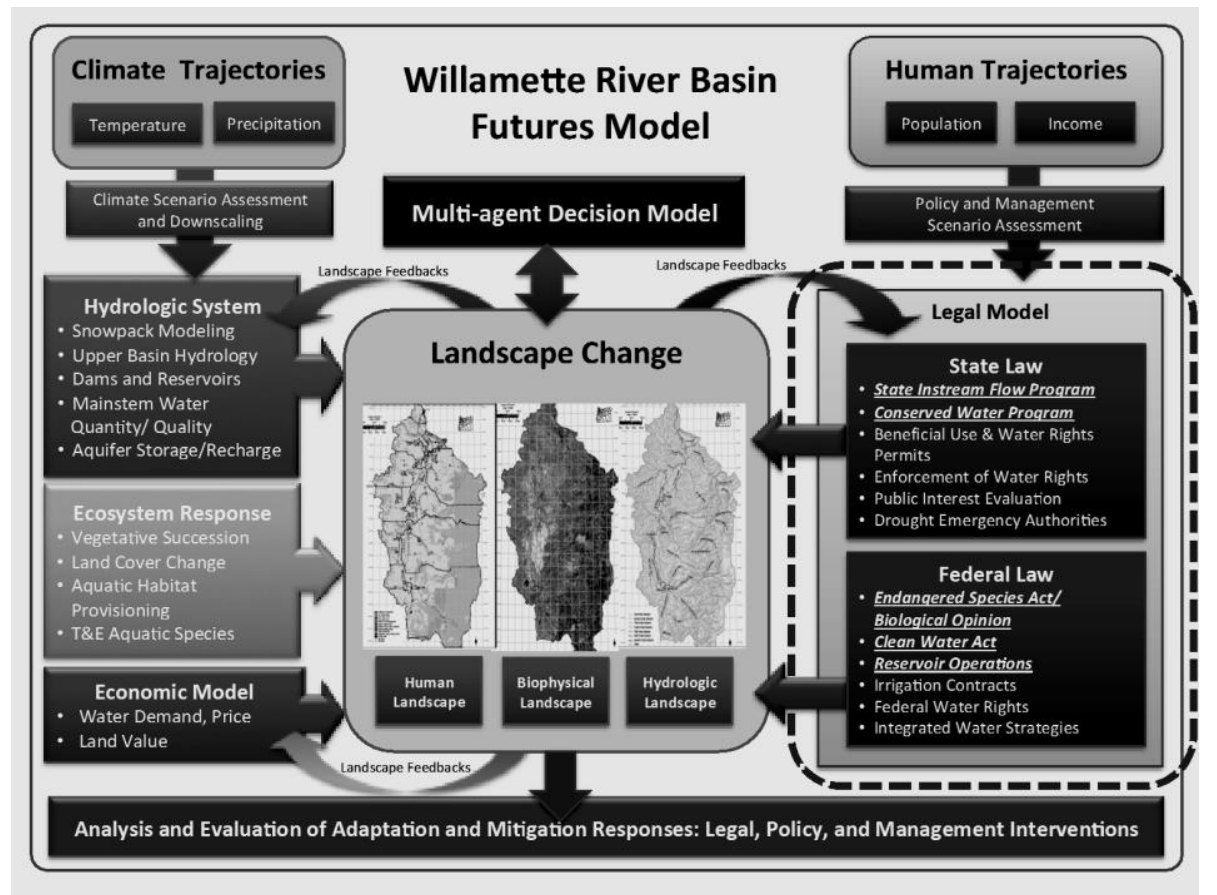

Figure 1-Developed by WW 2100 Researchers, Oregon State University, University of Oregon, and Portland State University, available online at enr.uoregon.edu wrbmodel

As Figure 1 and previous paragraphs make clear, the reach of federal and state water law in a system like the Willamette Basin is both wide and deep. Because water plays such a central role in human and natural processes, it is useful to distinguish between two broad conceptions of water shortage: water scarcity and water deficits. Put simply, water scarcity is fundamentally a normative, anthropocentric concept having to do with those times and places when there is a fixed amount of water that is insufficient to fully satisfy all competing human uses for it. ${ }^{243}$ Water

243. W. K. Jaeger et al., Toward a Formal Definition of Water Scarcity in Natural-Human Systems, 49 WATER RES. RESEARCH 4506, 4506-17 (2013). 
scarcity reflects human values and preferences, and it occurs when there is insufficient water to fulfill human wants and needs. We distinguish this concept of water scarcity from the related, but purely descriptive, notion of water deficit, which occurs when available water is insufficient for some biophysical process, such as the evapotranspirative needs of a forest or the spawning needs of aquatic life. Whether a deficit translates into scarcity in a given situation depends on people's values and society's preferences.

In terms of the stages of the legal work, we plan to focus, among the myriad ways that water matters to society, on water flows and water temperature. Both the flow regime through the streams and rivers of the Willamette Basin and the temperature of that water are amenable to operational definitions of scarcity and deficit. Also, both water scarcity and deficits are central measures of the sociocultural and biophysical importance of water. Lastly, both are reflected in key state and federal laws governing water and its use. This article focuses on the components of federal and state water law that are the most significant drivers for flow and temperature in the WRB.

Governance of freshwater at the state level centers on a wide range of issues associated with the prior appropriation doctrine including defining beneficial use, the allocation of water rights permits, the enforcement of priority, the measurement of diversions and water use, evaluating the public interest at the time of any water transfer, and implementing existing instream flow programs. ${ }^{244}$ Many of these provisions of state law may have unutilized flexibility that could help address water scarcity in the future. For the next step of analysis proposed for this project, however, the intention is to focus first on the provisions of state law that impact an increasingly important point of water conflict - the presence of instream flow rights.

With regard to federal law, governance of freshwater centers on a very fragmented set of environmental statutes and various common law doctrines ranging from the Endangered Species Act and associated Biological Opinions, contracting authority for water stored in federal reservoirs, the Clean Water Act, and the presence of federal water rights, to policy efforts to create a more integrated water strategy that coordinates all federal actions on a river, to name a few. Questions remain about the discretionary authority of the USACE on the timing and magnitude of flows in basins with federally managed reservoirs.

244. Amos, supra note 9, at 133-35. 
Because the mainstem flow of the Willamette River is largely controlled by releases from these reservoirs, this project will investigate the role of discretion in the day-to-day operations of the thirteen federal reservoirs on the system. To understand the decisions that are made by the USACE regarding the coordinated releases from these thirteen reservoirs, the project will focus first on an analysis to understand the federal statutory law that defines the purposes for which the USACE can operate these facilities and describe the operational flexibility and discretionary authority that these laws provide to the dam managers to address issues like instream flow.

\section{NEXT STEPS}

The work of the ongoing WW 2100 efforts and ideas for future research projects represent a new effort to integrate law and policy change into a hundred-year anticipatory modeling framework. This work has been initiated as part of the WW 2100 project, where economists have developed models of urban, agricultural, and recreational water use and land use, incorporating behavioral feedbacks and responses to scarcity common in economic models. As this work moves forward, the intent is to focus on some selected components of state and federal water law to build out the modeling capacity around those provisions of law. By delving deeply into particular aspects of state and federal law that impact instream flow, the hope is to begin to understand the flexibility and proactive tools that law and policy change can bring to the forefront as we experience change in water availability in the Willamette Basin. Some members of the WW 2100 research team have submitted a proposal for additional funding with the National Science Foundation to extend this analysis using an agent-based version of Envision. However, the underlying law and policy infrastructure - the so-called Law of the Willamette River-that we are building remains the same in each modeling approach. This legal work represents the integration of legal scholarship into those efforts and lies at the heart of the contributions that the law faculty and students have and will continue to provide. This integration focuses on law's capacity to be deployed as a proactive, problem-solving force and will focus, in its next stage, on the particulars set forth below.

Oregon state water law recognizes the authority of state agencies to assert instream flow rights to protect a variety of purposes including fish 
and wildlife, water quality, and recreation. ${ }^{245}$ We hypothesize that these authorities have not been utilized to their full capacity and, if they were, that these authorities could secure sufficient water in the Willamette River to address instream flow requirements for fish and water quality issues while meeting other out of stream demands. In particular, the project intends to ask:

What are each responsible agency's legal and policy authorities to assert instream water rights?

What process does each responsible agency use to determine if and when it should assert a water right?

If asserted, what process is used to evaluate the water rights application?

If the water right is granted, what enforcement mechanisms control the exercise of the water right?

Within existing legal authority, what quantity of water could be protected using each agency's parameters for asserting instream flow rights?

The approach to evaluating this hypothesis will: (a) use standard legal research method tools ${ }^{246}$ to build a description of each agency's relevant statutory, regulatory, and policy framework for asserting and maintaining instream flow rights; (b) outline the process for determining if and how the agency asserts a water right; (c) conduct interviews ${ }^{247}$ to better understand the circumstances under which each agency chooses to utilize these authorities and what impediments to the exercise of these discretionary authorities may exist; (d) assemble an inventory and catalog all existing instream flow rights and determine if enforcement actions have ever been necessary to protect them; and (e) use Envision's capacity to model flow regimes that more fully utilize the discretionary authority to assert instream flow rights for these various purposes.

This line of inquiry will hopefully expand the set of tools that are available to decision makers as they begin to address the flow regime for the Willamette River. For example, the Biological Opinion developed under the federal Endangered Species Act is one tool for addressing the

245. OR. REV. STAT. § 390.835(1).

246. For a general discussion of these standard legal research method tools, refer to either THE Process of Legal ReSEARCH, Authorities AND Options by Christina L. Kunz and others or OREGON LEGAL RESEARCH by Suzanne E. Rowe.

247. See generally Robert S. WeISS, LEARNING FROM StRANGERS: THE ART AND METHOD OF QUALITATIVE INTERVIEW STUDIES 14-83 (1995) (providing an overview of the stages involved in the interview process). 
flow requirements in the Willamette River. To date the Biological Opinion has been the primary mechanism for addressing flow requirements. By exploring the state's existing instream flow authority there may be state law mechanisms that are available for addressing the flow regime. By expanding the legal and policy options that are available, decision makers can develop a matrix of federal and state authorities and contextualize those authorities that recognize the particulars of the Willamette River system. The integration of state and federal law enhances the law's adaptive capacity to address changes to the freshwater system and de-emphasizes the reactive, one-tool approach that is so common in western river systems.

At the federal level, the authorities and responsibilities of federal agencies tasked with various aspects of river management, including the USACE, the Bureau of Reclamation (USBR), and the National Marine Fisheries Services, create the legal context for the Willamette River. In addition to the particular responsibilities of these agencies, each of these agencies is also responsible for compliance with a host of additional federal statutes, including, most significantly on the Willamette River, the Endangered Species Act and the Clean Water Act. This research hypothesizes that these authorities have not been fully explored to address the need for flexibility in managing the Willamette River system. To evaluate the validity of this hypothesis, this project intends to ask:

What federal statutory and regulatory authorities govern the operations on the Willamette River regarding the impoundment and release of water? What is the scope of discretion given to the agencies to manage the flow on the Willamette River?

What federal court decisions are applicable to the exercise of discretionary authorities that govern the impoundment and release of water on the Willamette River?

What process do these agencies follow in determining how to use their discretionary authority to alter the flow patterns on the Willamette River?

How much of the decision making process is controlled by legal requirements and how much of the decision is the exercise of sound professional judgment in the context of authorized agency discretion?

How much variability in release patterns is available within existing discretionary authority to alter the flows in the Willamette River downstream of the thirteen federal reservoirs? 
The approach will: (a) use standard legal research methods ${ }^{248}$ to build a description of the statutory and regulatory authorities that govern the operation of the federal reservoirs managed on the Willamette River and the non-reservoir statutory and regulatory frameworks that impact the reservoir operations; (b) use standard legal research methods ${ }^{249}$ to catalog and describe the relevant federal court decisions that impact the exercise of discretionary legal authority on the part of the relevant federal agencies on the Willamette River; (c) conduct interviews to better understand the process used by the relevant agencies to determine how and when to exercise available discretionary authority; (d) use Envision's capacity to model flow regimes that more fully utilize the discretionary authority available to the relevant agencies to change the release patterns from the thirteen federal reservoirs on the Willamette River.

This line of inquiry seeks to explore the scope of federal discretionary authority that could be applied on the Willamette River. Full understanding of the overlay and scope of federal authority expands the set of tools that are available to decision makers as they begin to address the flow regime for the Willamette River. For example, the operations undertaken by the USACE for thirteen reservoirs on the Willamette River exert the predominant influence on river flows. To the extent there are unutilized discretionary authorities that the USACE could implement, the results of this research will facilitate the proactive response to issues of water scarcity or water quality on the downstream system in highly transferable ways. The integration of state authorities described above with the federal law mechanisms described here may enhance the adaptive capacity to proactively address changes to the freshwater system and de-emphasize the reactive, one-tool approach that is so common in western river systems.

Once this legal research is complete, the resulting legal infrastructure will integrate into the Envision capabilities and then evaluate the results that Envision produces. The hope is that this legal infrastructure can be deployed in various future modeling efforts both within and beyond the WW 2100 project. These representations include: the most current Intergovernmental Panel on Climate Change, climate change projections

248. For a general discussion of these standard legal research methods, refer to FEDERAL LEGAL RESEARCH by Mary G. Algero.

249. For a general discussion of these standard legal research method tools, refer to either Christina L. KunZ et AL., The Process of Legal Research, Authorities AND OPTIONS (2012) or J.D.S. ARMSTRONG ET AL., Where the LAW Is: AN INTRODUCTION TO ADVANCED LEGAL RESEARCH (2008). 
on temperature and precipitation chosen specifically for conditions in the Pacific Northwest; population growth projections through the year 2100; all surface water rights, point of withdrawal, point of return, points of use, percent consumed, beneficial use, and seniority date at the stream reach level of detail; and others.

Through these tools, we can assess factors such as the rate of change in water rights going unmet due to the change in precipitation versus water rights going unmet as a result of reservoir management mandated by a Biological Opinion under the Endangered Species Act. Different discretionary choices might avoid the same levels of scarcity for a given location, but require changes in the interplay of federal and state legal frameworks to do so. We can also identify landscape areas that have greater vulnerabilities to changes in discretionary authority or require different types of adaptation to achieve similar reductions in water scarcity. Thus, there might be areas in the landscape that could see reductions in scarcity under many levels of discretion in reservoir management, as opposed to other areas that might only exhibit reductions under a single or very few specific levels of discretion.

The last phases of the legal research will synthesize the outcomes from the work described above, and developed through other modeling efforts, to determine what types of legal and policy measures will provide greater resiliency and adaptability in the WRB's water management. The intent is to look not only at the substantive issues, but to also evaluate the procedural steps towards implementation of preferred legal and policy approaches that will most likely achieve the desired outcomes. The project will be built with stakeholder input along the way to hopefully provide information about the flexibility within the state and federal legal frameworks to allow for adaptability in light of climate and population change while demonstrating to decision makers in Oregon how anticipatory modeling can integrate with dynamic governance and legal decision making to respond to unprecedented hydrological, ecological, and socio-economic changes. 